Prepared in cooperation with Bureau of Reclamation, Yakama Nation Fisheries, and Washington Department of Fish and Wildlife

\title{
Evaluation of Factors Affecting Migration Success of Adult Sockeye Salmon (Oncorhynchus nerka) in the Yakima River, Washington, 2020
}
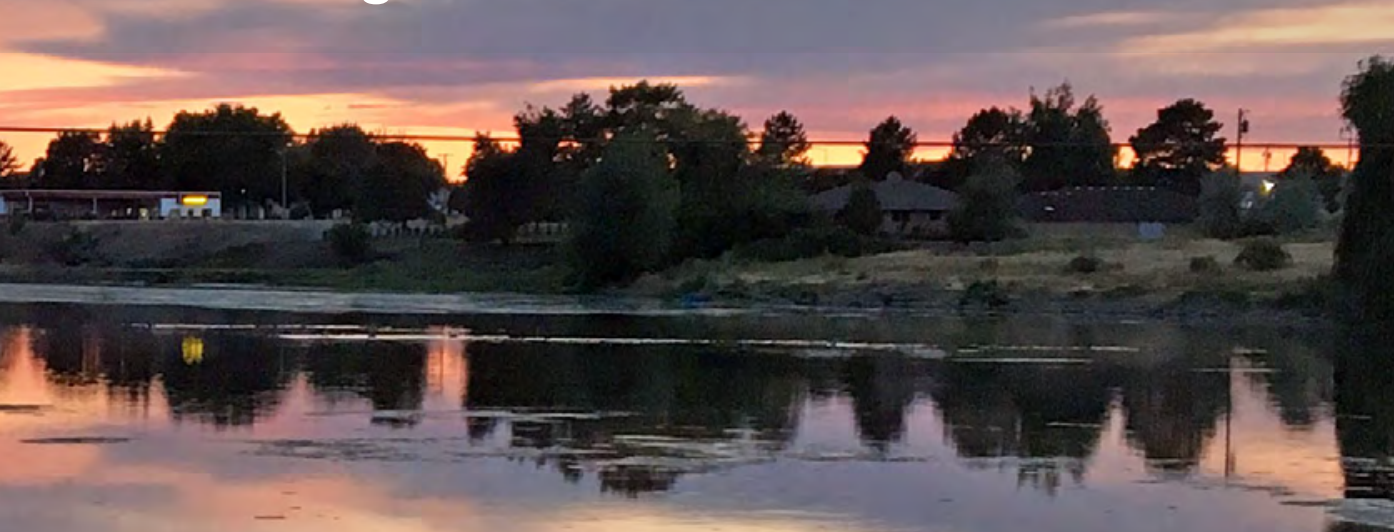

Open-File Report 2021-1075

U.S. Department of the Interior U.S. Geological Survey

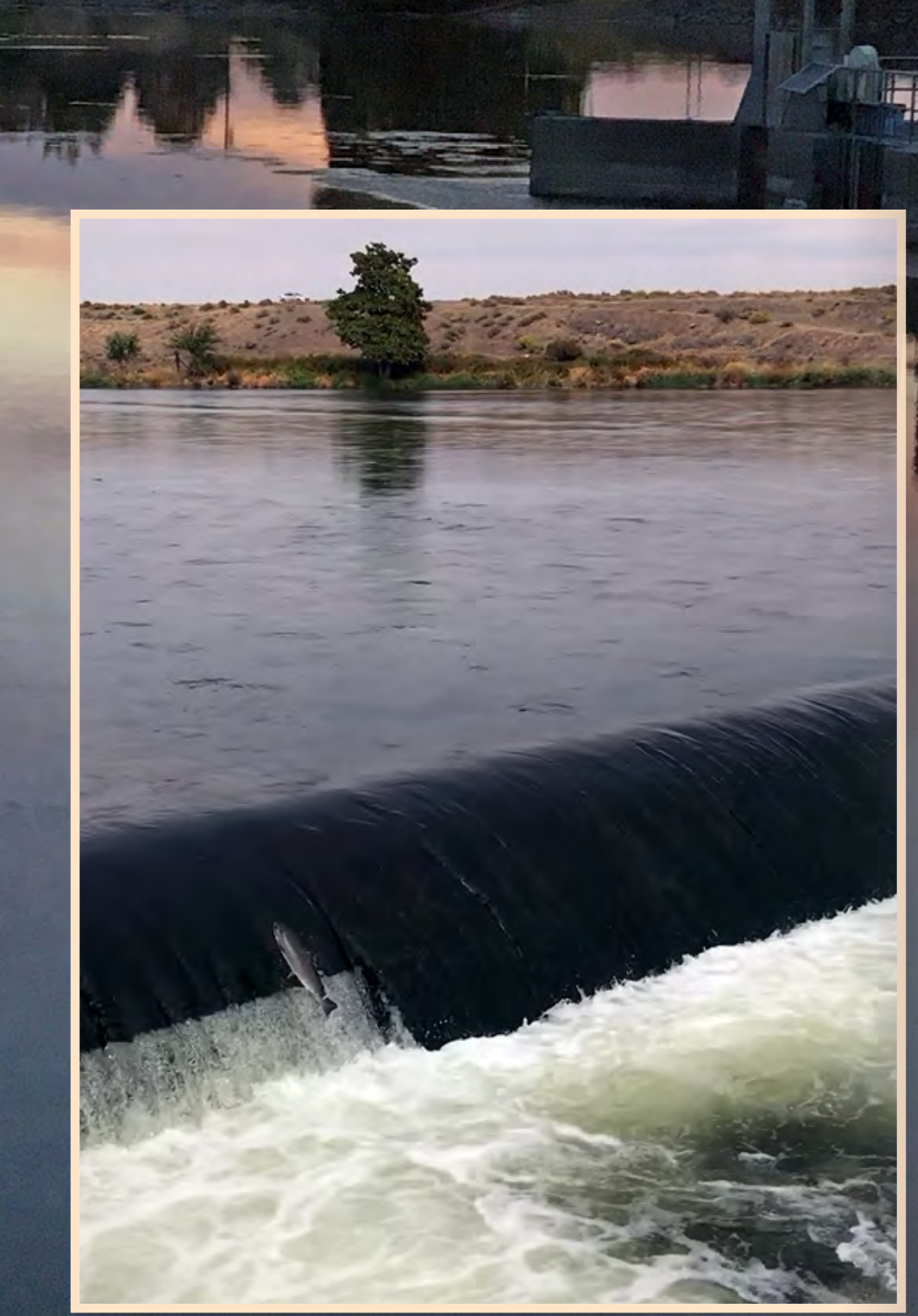


Cover:

Background image: Forebay of Prosser Dam, Yakima River, Washington.

Photograph by Tobias J. Kock, U.S. Geological Survey, June 24, 2019.

Inset image: Adult sockeye salmon (Oncorhynchus nerka) attempting to jump over Wanawish Dam, Yakima River, Washington. Photograph by Ryan Tomka, U.S. Geological Survey, September 23, 2020. 


\section{Evaluation of Factors Affecting Migration Success of Adult Sockeye Salmon (Oncorhynchus nerka) in the Yakima River, Washington, 2020}

By Tobias J. Kock, Amy C. Hansen, Scott D. Evans, Richard Visser, Brian Saluskin, Andrew Matala, and Paul Hoffarth

Prepared in cooperation with Bureau of Reclamation, Yakama Nation Fisheries, and Washington Department of Fish and Wildlife

Open-File Report 2021-1075 


\section{U.S. Geological Survey, Reston, Virginia: 2021}

For more information on the USGS - the Federal source for science about the Earth, its natural and living resources, natural hazards, and the environment—visit https://www.usgs.gov or call 1-888-ASK-USGS.

For an overview of USGS information products, including maps, imagery, and publications, visit https://store.usgs.gov/.

Any use of trade, firm, or product names is for descriptive purposes only and does not imply endorsement by the U.S. Government.

Although this information product, for the most part, is in the public domain, it also may contain copyrighted materials as noted in the text. Permission to reproduce copyrighted items must be secured from the copyright owner.

Suggested citation:

Kock, T.J., Hansen, A.C., Evans, S.D., Visser, R., Saluskin, B., Matala, A., and Hoffarth, P., 2021, Evaluation of factors affecting migration success of adult sockeye salmon (Oncorhynchus nerka) in the Yakima River, Washington, 2020: U.S. Geological Survey Open-File Report 2021-1075, 30 p., https://doi.org/10.3133/ofr20211075.

ISSN 2331-1258 (online) 


\section{Acknowledgments}

Yakama Nation Fisheries provided labor, fish transport, and tagging support during the study. We also appreciate the efforts of Alan Butler, John Butenhoff, Ken Baird, Robert Brigantic, Greg Couch, David Dalan, Jacob Dalan, Joe Jancovic, Jeff Jones, Eric McCrea, John Merk, Phil Moytka, Craig Nelson, Thor Ostrom, George Pressler, Jack Ramynke, Jason Ramynke, Marggie Ramynke, Greg Reault, Spencer Reiboldt, Tony Reiboldt, Teddy Schmitt, Cory Scott, Barry Shoemake, Jay Southwick, and Chris Tanahill, who served as volunteer anglers to collect adult sockeye salmon that were tagged and released at the Yakima River mouth. The Washington State Department of Ecology was a partner on this study, and we appreciate their involvement.

We thank Brian Ekstrom, Philip Haner, Gabriel Hansen, and Ryan Tomka of the U.S. Geological Survey for their field efforts. 


\section{Contents}

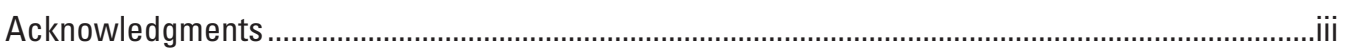

Abstract

Introduction

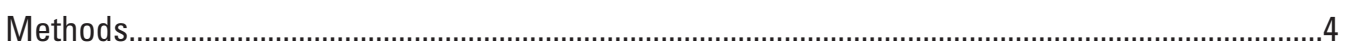

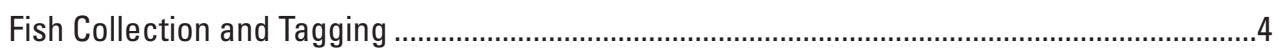

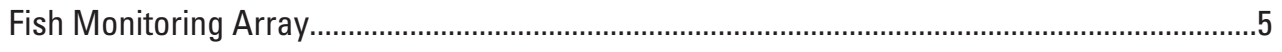

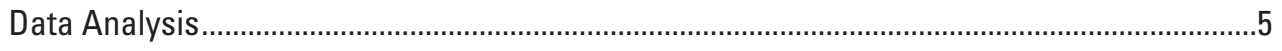

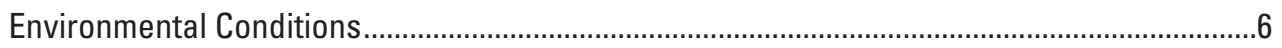

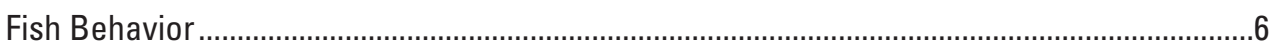

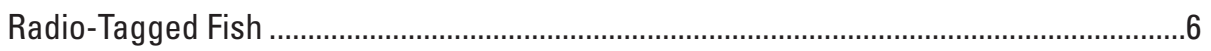

Passive Integrated Transponder-Tagged Fish ....................................................................

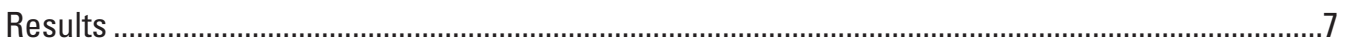

Environmental Conditions .......................................................................................................

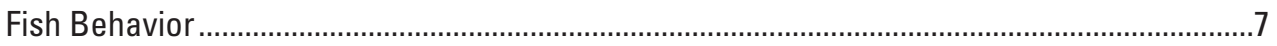

Radio-Tagged Sockeye Salmon Released at Prosser Dam ..........................................

Radio-Tagged Sockeye Salmon Released at Yakima River Mouth....................................7

Passive Integrated Transponder-Tagged Sockeye Salmon Released at Yakima

River Mouth ......................................................................................................... 14

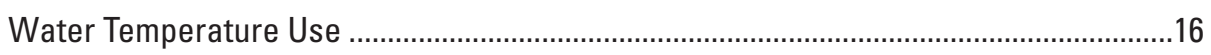

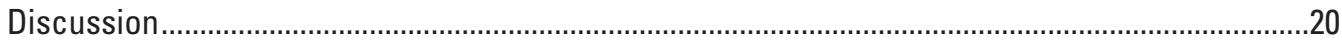

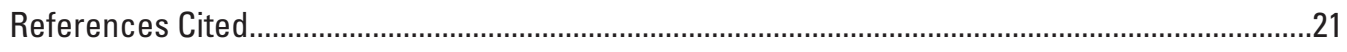

Appendix 1. Temperature Use Records from Recovered Transmitters ........................................25

\section{Figures}

1. Graphs showing daily percentage of the total run of adult sockeye salmon passing Prosser Dam in the Yakima River and McNary Dam on the Columbia River, and daily water temperature on the Yakima and Columbia Rivers, Washington, June-0ctober 2013-20.

2. Image showing locations of fish release sites and fixed radio telemetry monitoring sites used to detect tagged fish in the Yakima and Columbia Rivers, Washington

3. Graph showing sockeye salmon tagging dates, mean daily river flow in the Yakima River, mean daily water temperature in the lower Yakima River, and mean daily water temperature in the Columbia River near Richland, Washington, June 1-0ctober 1, 2020.

4. Graph showing water temperature use data collected by a radio transmitter inside an adult sockeye salmon released at the mouth of the Yakima River on June 20, 2020

5. Graph showing mean daily water temperature as measured at the Van Giesen Bridge in Richland, and number of radio-tagged sockeye salmon that entered the Yakima River and were detected on a fixed site, Washington, 2020.

6. Graph showing water temperature use data collected by a radio transmitter inside an adult sockeye salmon (fork length 49 centimeters) released the mouth of the Yakima River on August 7, 2020. 
7. Graph showing water temperature use data collected by a radio transmitter inside an adult sockeye salmon (fork length 53 centimeters) released the mouth of the Yakima River on August 7, 2020.

8. Graph showing residence time by diel arrival period for radio-tagged adult sockeye salmon at fixed telemetry sites on the lower Yakima River, Washington, 2019-20..

9. Pie diagrams showing percentages of detected passive integrated transponder-tagged adult sockeye salmon at final locations by release month after release at the mouth of the Yakima River, Washington, 2020

10. Graph showing number of passive integrated transponder-tagged sockeye salmon arriving at Prosser Dam by date in the Yakima River after tagging at Bonneville Dam, the mouth of the Yakima River, and Priest Rapids Dam, Washington, 2020

11. Graphs showing hour of first arrival of passive integrated transponder-tagged sockeye salmon at Prosser Dam in the Yakima River, after tagging at Bonneville Dam, the mouth of the Yakima River, and Priest Rapids Dam, Washington, 2020..

12. Graph showing hour of passive integrated transponder-tagged sockeye salmon arrival at Prosser and Roza Dams in the Yakima River, Washington, 2020.

13. Graph showing number of adult passive integrated transponder-tagged sockeye released in the Columbia River Basin that only were detected at Prosser Dam and both Prosser and Roza Dams, Washington, 2020.

14. Photograph showing dorsal wound on an adult sockeye salmon trapped for radio-tagging at Prosser Dam, Washington, on June 26, 2019.

\section{Tables}

1. Number of adult sockeye salmon returning annually to Prosser and Roza Dams, Yakima River, Washington, 2013-20

2. Number of adult sockeye salmon collected and tagged on the lower Yakima River, Washington, 2020. .4

3. Study reach descriptions used in this report

4. Final locations of radio- and passive integrated transponder-tagged adult sockeye by release month after collection and release at the mouth of the Yakima River, Washington, 2020

5. Detection history of passive integrated transponder-tagged adult sockeye salmon released at the mouth of the Yakima River in river reaches by chronological detection history and release month, Washington, 2020

6. Number of passive integrated transponder-tagged sockeye salmon detected at Prosser and Roza Dams in the Yakima River, and the percentage of fish that successfully arrived at Roza Dam after passing Prosser Dam (percentage successful), by week of arrival at Prosser Dam, Washington, 2020 . 


\section{Conversion Factors}

International System of Units to U.S. customary units

\begin{tabular}{|c|c|c|}
\hline Multiply & By & To obtain \\
\hline \multicolumn{3}{|c|}{ Length } \\
\hline centimeter $(\mathrm{cm})$ & 0.3937 & inch (in.) \\
\hline millimeter $(\mathrm{mm})$ & 0.03937 & inch (in.) \\
\hline meter $(\mathrm{m})$ & 3.281 & foot $(\mathrm{ft})$ \\
\hline kilometer (km) & 0.6214 & mile (mi) \\
\hline meter $(\mathrm{m})$ & 1.094 & yard (yd) \\
\hline \multicolumn{3}{|c|}{ Volume } \\
\hline liter $(\mathrm{L})$ & 33.81402 & ounce, fluid (fl. oz) \\
\hline \multicolumn{3}{|c|}{ Flow rate } \\
\hline cubic foot per second $\left(\mathrm{ft}^{3} / \mathrm{s}\right)$ & 0.02832 & cubic meter per second $\left(\mathrm{m}^{3} / \mathrm{s}\right)$ \\
\hline
\end{tabular}

Temperature in degrees Celsius $\left({ }^{\circ} \mathrm{C}\right)$ may be converted to degrees Fahrenheit $\left({ }^{\circ} \mathrm{F}\right)$ as follows:

$$
{ }^{\circ} \mathrm{F}=\left(1.8 \times{ }^{\circ} \mathrm{C}\right)+32 .
$$

\section{Abbreviations}

$\begin{array}{ll}\text { PIT } & \text { passive integrated transponder } \\ \text { rkm } & \text { river kilometer } \\ \text { Reclamation } & \text { Bureau of Reclamation } \\ \text { USGS } & \text { U.S. Geological Survey }\end{array}$




\title{
Evaluation of Factors Affecting Migration Success of Adult Sockeye Salmon (Oncorhynchus nerka) in the Yakima River, Washington, 2020
}

\author{
By Tobias J. Kock, ${ }^{1}$ Amy C. Hansen, ${ }^{1}$ Scott D. Evans, ${ }^{1}$ Richard Visser, ${ }^{2}$ Brian Saluskin, ${ }^{3}$ Andrew Matala, ${ }^{3}$ and \\ Paul Hoffarth 4
}

\section{Abstract}

A study was conducted during June-October 2020 to evaluate factors affecting the migration success of adult sockeye salmon (Oncorhynchus nerka) in the Yakima River, Washington. A total of 144 adult sockeye salmon were tagged and released during the study. Most fish (112 fish) were collected, tagged with passive integrated transponder (PIT), and released at the mouth of the Yakima River. The remaining fish were tagged with a radio transmitter and PIT tag: 13 fish were collected, tagged, and released at Prosser Dam; 13 fish were collected and tagged at Prosser Dam, transported downstream, and released at the mouth of the Yakima River; and 6 fish were collected, tagged, and released at the mouth of the Yakima River. Radio-tagged fish released at Prosser Dam initially moved upstream and spread out in the river reach between Prosser and Sunnyside Dams, but all fish stopped moving and several transmitters were recovered. Detection records and temperature data from recovered transmitters were the basis for inferring that avian predators consumed at least 6 of the 13 fish. Fifteen of the 19 radio-tagged sockeye salmon released at the mouth of the Yakima River moved upstream in the Columbia River and were detected at Johnson Island in the Hanford Reach, or at Priest Rapids Dam. Two of these fish, tagged on August 7, eventually moved back downstream and entered the Yakima River when water temperatures in the lower Yakima River were $16-18$ degrees Celsius $\left({ }^{\circ} \mathrm{C}\right)$. One fish moved upstream to Sunnyside Dam where its tag was later recovered. The other fish moved farther upstream and was detected at Prosser Dam, but eventually moved downstream and its tag was recovered near Benton City, Washington. None of the recovered tags were found near a carcass. More than one-half of the sockeye salmon that were collected, tagged, and released at the mouth of the Yakima River were

\footnotetext{
${ }^{1}$ U. S. Geological Survey

${ }^{2}$ Bureau of Reclamation

${ }^{3}$ Yakama Nation Fisheries

${ }^{4}$ Washington Department of Fish and Wildlife
}

subsequently detected, and the greatest proportion of fish from groups released during June, July, and August entered the Yakima River. This finding suggests that adult sockeye salmon are present at the mouth of the Yakima River throughout the summer. Detection records for tagged fish at monitoring sites located near cool water inputs in the lower Yakima River suggest that sockeye salmon do not spend a substantial amount of time at these locations. Fish count data at Prosser Dam fish ladders showed that sockeye salmon had a bi-modal pattern of upstream migration with peaks in late June/early July and September when water temperature in the lower Yakima River was $20^{\circ} \mathrm{C}$ or less. Sixty-one percent of PIT-tagged sockeye salmon detected at Prosser Dam were eventually collected at the adult fish trapping facility at Roza Dam where fish are collected and transported upstream to Cle Elum Reservoir. These data, in conjunction with results from other studies, suggest that a substantial proportion of Yakima River sockeye salmon fail to arrive at Roza Dam. Additional research will be required to better understand factors affecting Yakima River sockeye salmon.

\section{Introduction}

The Yakima River, in Washington State, historically supported the largest run of sockeye salmon (Oncorhynchus nerka) in the Columbia River Basin, with an estimated 150,000-200,000 adults returning annually to spawn (Yakama Nation, 1990; Bureau of Reclamation, 2005). Spawning historically occurred in four nursery lakes (Keechelus, Kachess, Cle Elum, and Bumping Lakes), but access to each of these lakes was blocked by dams constructed during 1904-10 (Yakama Nation, 1990). The construction of these dams prevented returning adult sockeye salmon from accessing the nursery lakes and the population eventually was extirpated. As a result, sockeye salmon were absent from the Yakima River for a century until efforts were initiated in the 2000s to reintroduce anadromous fish populations to areas they historically occupied (Bureau of Reclamation, 2005; Matala and others, 2019). 
In 2002, as part of a settlement agreement with the Yakama Nation, the Bureau of Reclamation (Reclamation) agreed to evaluate the feasibility of constructing fish passage structures at five reservoir dams in the Yakima Basin, eventually determining that this was feasible (Bureau of Reclamation, 2005, 2011). After the feasibility determination, Cle Elum Dam was chosen as the first site where fish passage facilities were to be constructed. The Yakama Nation and Washington Department of Fish and Wildlife began planning to reintroduce sockeye salmon into the Yakima Basin and in 2009 Yakama Nation began releasing adult sockeye salmon into Cle Elum Reservoir. The initial reintroduction consisted of outplanting 1,000 adult sockeye salmon into the reservoir where they could spawn along shorelines or move upstream into the Cle Elum River for spawning. Outplanted fish originating from either the Wenatchee River or Okanogan River were collected for translocation at Priest Rapids Dam on the main-stem Columbia River during annual spawning migrations (Matala and others, 2019). Monitoring indicated that outplanted adults were able to successfully spawn upstream from Cle Elum Dam and produce progeny that eventually migrated to the ocean (Brian Saluskin, Yakama Nation, oral commun., July 2017). Based on this success, annual outplanting efforts have continued since 2009 and in some years as many as 10,000 adult sockeye salmon collected at Priest Rapids Dam have been released into the reservoir. These releases now include fish from three origins: Wenatchee River and Okanogan River sockeye salmon from Priest Rapids Dam and Yakima River sockeye salmon that return to the basin for spawning. The latter fish are progeny of outplanted sockeye salmon that spawned naturally in Cle Elum Reservoir and in the Cle Elum River. The number of adult sockeye salmon that returned to the Yakima River and were collected at Roza Dam has varied substantially from a low of 95 fish to a high of 4,379 fish since 2013 (table 1).

Adult sockeye salmon pass McNary Dam (located 69 river kilometers [rkm] downstream from the Yakima River mouth) during June-August (fig. 1) each year; spawning in the upper Yakima River Basin occurs from late September

Table 1. Number of adult sockeye salmon returning annually to Prosser and Roza Dams, Yakima River, Washington, 2013-20.

\begin{tabular}{ccc}
\hline Year & $\begin{array}{c}\text { Number of fish at } \\
\text { Prosser Dam }\end{array}$ & $\begin{array}{c}\text { Number of fish at } \\
\text { Roza Dam }\end{array}$ \\
\hline 2013 & 696 & 691 \\
2014 & 2,678 & 2,576 \\
2015 & 342 & 95 \\
2016 & 3,742 & 3,949 \\
2017 & 372 & 137 \\
2018 & 456 & 201 \\
2019 & 110 & 201 \\
2020 & 2,549 & 4,379 \\
\hline
\end{tabular}

through November (Matala and others, 2019). Migratory conditions in the lower Yakima River are extreme, where water temperatures commonly exceed 24 degrees Celsius $\left({ }^{\circ} \mathrm{C}\right)$ when summer air temperature peaks (Appel and others, 2011). This environment is believed to deter fish from entering the river and moving upstream because sockeye salmon are observed passing Prosser Dam when this occurs. This phenomenon, referred to as a "thermal block," has been documented for sockeye salmon at several locations including the Fraser River (migration blocked at $18-22^{\circ} \mathrm{C}$; Macdonald and others, 2000), and the Okanogan River (migration blocked at $21-23^{\circ} \mathrm{C}$; Major and Mighell, 1967; Hatch and others, 1993) in British Columbia, Canada, and the Snake River in Washington (migration blocked at $22^{\circ} \mathrm{C}$; Quinn and others, 1997). In addition to preventing adult sockeye salmon from entering the Yakima River during part of their normal migration period, elevated water temperature in the Yakima and Columbia Rivers has the potential to increase mortality of sockeye salmon adults, which has been documented in numerous studies throughout the Pacific Northwest (Rand and others, 2006; Keefer and others, 2008; Mathes and others 2010; Eliason and others, 2011; Jeffries and others, 2012; Martins and others, 2012; National Oceanic and Atmospheric Administration, 2016).

Although elevated summer water temperature is a threat to adult sockeye salmon in the lower Yakima River, research by Appel and others (2011) has identified several cool water inputs near locations where groundwater discharge seeps and stream mouths enter the river. These areas of incoming cool water have the potential to provide thermal refuge and benefit adult sockeye salmon if they locate in and use them as a source of thermal relief during extended warm periods. Sites such as these have been described in other systems as cool water (or cold water) refugia and are hypothesized to benefit fish species that encounter them (Ebersole and others 2001; U.S. Environmental Protection Agency, 2012; Hess and others, 2016). As an example, Ebersole and others (2003) reported that the increasing frequency and size of cold-water patches were associated with increased abundances of rainbow trout (Oncorhynchus mykiss) and Chinook salmon (Oncorhynchus tshawytscha) in northeastern Oregon.

A telemetry study was conducted during JuneOctober 2020 to evaluate factors affecting migration of adult sockeye salmon in the Yakima River. This study follows a pilot study conducted during 2019 that included radio-tagging of 60 adult sockeye salmon released in the lower Yakima River and at the mouth of the Yakima River mouth in June and July (Kock and others, 2020). Tagged fish released in the river in June moved downstream and out of the Yakima River several days after release when water temperature increased from $20^{\circ} \mathrm{C}$ to greater than $25^{\circ} \mathrm{C}$ (Kock and others, 2020). Tagged sockeye salmon failed to reenter the Yakima River until September when water temperature decreased to less than $20^{\circ} \mathrm{C}$ and only 1 of the 60 tagged fish eventually moved upstream to Roza Dam where fish are collected and transported to a release site on the Cle Elum River 


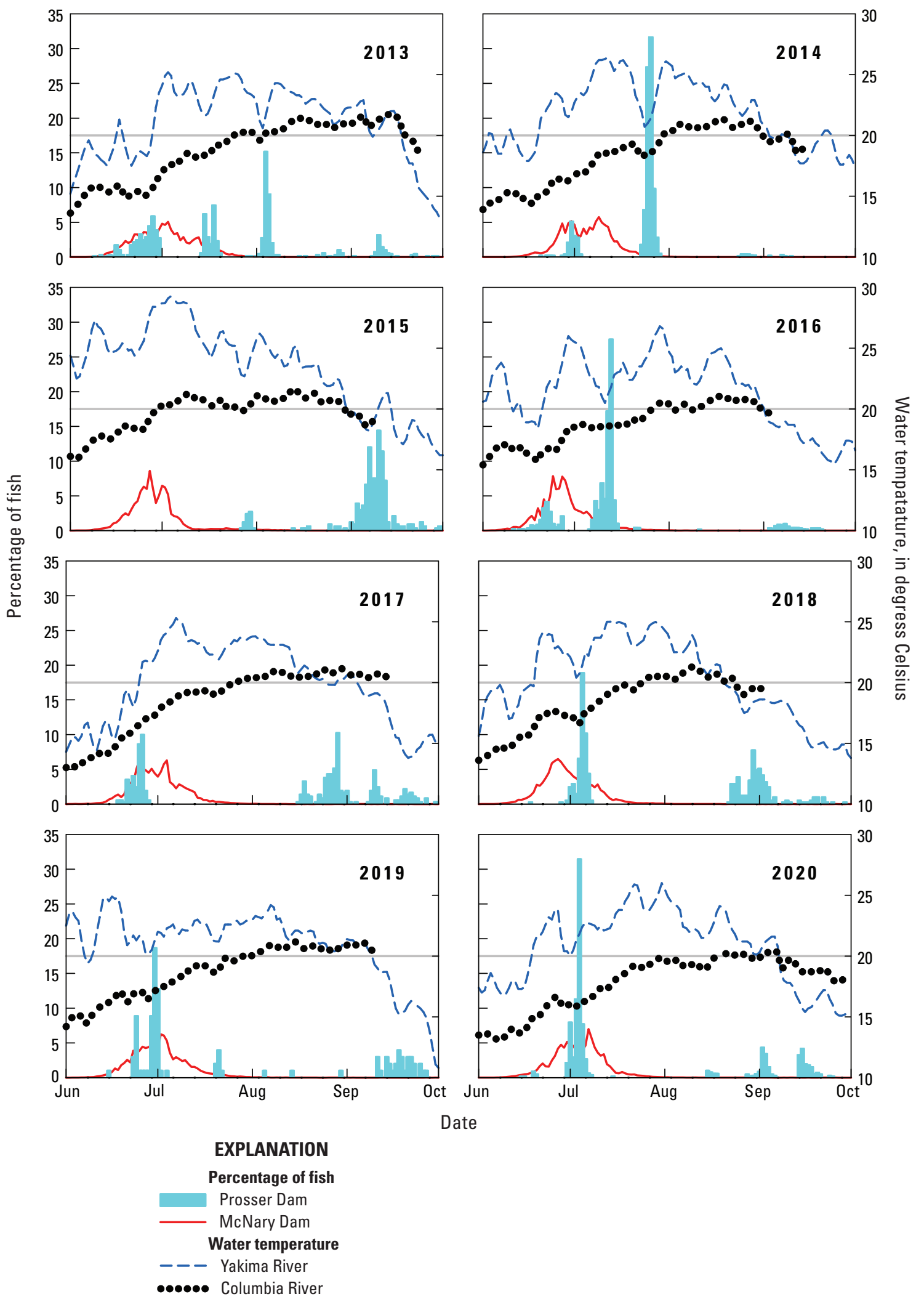

Figure 1. Daily percentage of the total run of adult sockeye salmon passing Prosser Dam in the Yakima River (light-blue bars) and McNary Dam on the Columbia River (solid red line), and daily water temperature on the Yakima (dashed blue line) and Columbia (black dotted line) Rivers, Washington, June-October 2013-20. Horizontal gray line at 20 degrees Celsius is included for reference. 
(Kock and others, 2020). The 2020 study was designed to further assess factors affecting migration of adult sockeye salmon in the Yakima River. All study fish were tagged with a PIT tag and a subset of these also were tagged with a temperaturesensing radio transmitter. Fish primarily were released at the mouth of the Yakima River to evaluate behavior and movement patterns from that location upstream to Roza Dam, but a few fish also were released at Prosser Dam. Results from the 2020 study are described in this report.

\section{Methods}

\section{Fish Collection and Tagging}

Adult sockeye salmon were collected, tagged, and released at two locations during the study. A total of 26 fish were collected and tagged with a radio transmitter and PIT tag at Prosser Dam from June 19 to June 22, 2020. One-half of the tagged fish (13 fish) were released into the forebay of Prosser Dam to resume upstream migration in the Yakima River. The remaining 13 fish were transported downstream by truck and released at the mouth of the Yakima River to collect information on fish behavior downstream from Prosser Dam (fig. 2; table 2). Additionally, 112 fish were collected, tagged, and released at the mouth of the Yakima River on three dates from June 26 to August 7, 2020 (fig. 2). All 112 fish were tagged with a PIT tag and 6 of these also were tagged with a radio transmitter (table 2).

Fish collected at Prosser Dam were trapped in the southernmost fish ladder (river right bank) at the dam. To operate the fish trap, a weir was lowered into the fish ladder to prevent fish from moving upstream past the weir and water was diverted from the ladder through a steeppass that had an entrance located immediately downstream from the weir. To enter the trap, fish moved upstream through the steeppass and fell about 1 meter $(\mathrm{m})$ into the wetted trap where they remained until tagging occurred. The trap was checked once per day at about 8:00 a.m. Fish tagged on June 19 and 20 were collected over approximately 24 hours whereas fish tagged on June 22 were collected over approximately 48 hours. Fish were hand netted from the trap and transferred to a 378-liter (L) holding tank that contained fresh river water. Each fish was measured to the nearest centimeter for fork length, sex was visually estimated, PIT tags were implanted into the pelvic girdle, and a radio transmitter (Lotek Wireless; Model MCFT3-EM-T-L ${ }^{\circledR}$; Newmarket, Ontario, Canada) was implanted gastrically using methods described in Keefer and others (2004). The transmitters contained a sensor that recorded body temperature at 1-minute intervals in addition to emitting a signal every 5 seconds. The transmitters were able to measure and record body temperature associated with water temperature throughout the range from -6 to $34{ }^{\circ} \mathrm{C}$. The record of body temperatures was downloadable when transmitters were recovered at the end of the study. After tagging, fish were transferred to a fish hauling truck for downstream transport to the lower river release site, transferred to a boat, and released in the center of the channel at the mouth of the Yakima River.

Angling was used to collect fish at the mouth of the Yakima River. The Washington Department of Fish and Wildlife organized a group of volunteer anglers to collect fish for tagging on three days (June 26, July 17, and August 7, 2020). On each day, a total of 26 anglers fished on six boats from about 5:00 a.m. until 10:00 a.m. The tagging crew operated a seventh boat that remained close to the angling boats. The tagging crew monitored the angling boats continuously and when fish were caught, pulled alongside individual boats to transfer fish to a 378-L holding tank filled with fresh river water. Each fish was tagged with a PIT tag, measured to the nearest centimeter for fork length, and its sex was visually estimated. Six of these fish also were tagged with a radio transmitter on August 7, 2020, using methods described earlier in this section. Tagged fish were released near the point of capture as soon as they appeared to be visibly recovered from the collection and tagging process.

Table 2. Number of adult sockeye salmon collected and tagged on the lower Yakima River, Washington, 2020.

[RT+PIT: Radio telemetry transmitter- plus passive integrated transponder-tagged. FL range: Fork length range; cm, centimeters. Abbreviations: NA, not applicable, data not available]

\begin{tabular}{|c|c|c|c|c|c|c|c|}
\hline \multirow[b]{2}{*}{ Collection location } & \multirow[b]{2}{*}{ Tagging date } & \multicolumn{2}{|c|}{ Prosser Dam } & \multicolumn{4}{|c|}{ Yakima River mouth } \\
\hline & & $\begin{array}{c}\text { RT+PIT } \\
\text { (number of fish) }\end{array}$ & $\begin{array}{l}\text { FL range } \\
(\mathrm{cm})\end{array}$ & $\begin{array}{c}\mathrm{RT}+\mathrm{PIT} \\
\text { (number of fish) }\end{array}$ & $\begin{array}{l}\text { FL range } \\
(\mathrm{cm})\end{array}$ & $\begin{array}{c}\text { PIT only } \\
\text { (number of fish) }\end{array}$ & $\begin{array}{l}\text { FL range } \\
(\mathrm{cm})\end{array}$ \\
\hline Prosser Dam & June 19, 2020 & 2 & $47-49$ & 2 & $48-50$ & NA & NA \\
\hline Prosser Dam & June 20, 2020 & 9 & $41-53$ & 9 & $45-49$ & NA & NA \\
\hline Prosser Dam & June 22, 2020 & 2 & $48-53$ & 2 & $47-49$ & NA & NA \\
\hline Yakima River mouth & June 26, 2020 & NA & NA & NA & NA & 12 & $46-52$ \\
\hline Yakima River mouth & July 17,2020 & NA & NA & NA & NA & 38 & $44-52$ \\
\hline \multirow[t]{2}{*}{ Yakima River mouth } & August 7, 2020 & NA & NA & 6 & $49-55$ & 62 & $45-56$ \\
\hline & Total fish tagged & 13 & $41-53$ & 19 & $45-55$ & 112 & $44-56$ \\
\hline
\end{tabular}




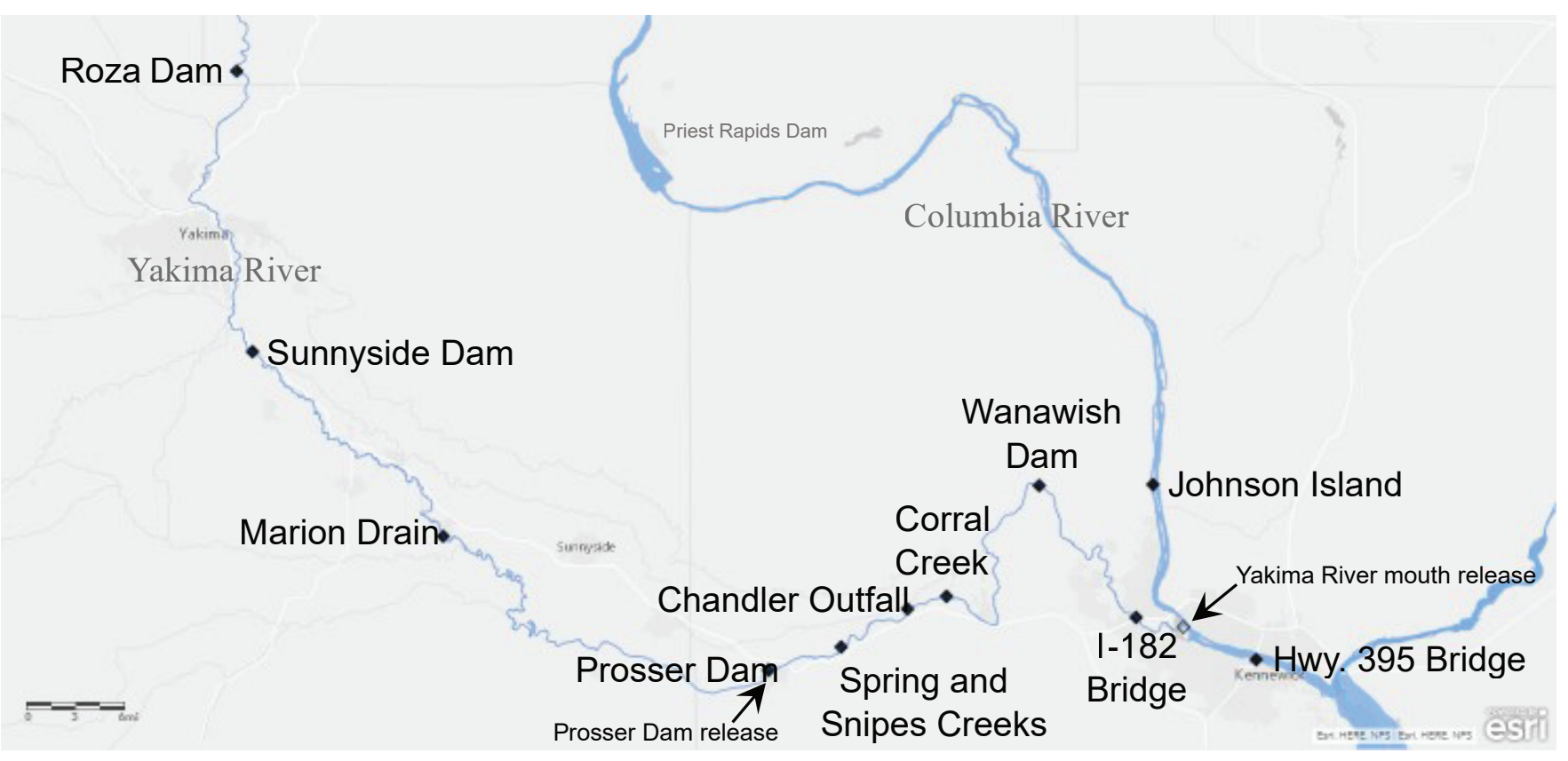

Figure 2. Locations of fish release sites (black arrows) and fixed radio telemetry monitoring sites (black closed diamonds) used to detect tagged fish in the Yakima and Columbia Rivers, Washington. Image is the intellectual property of Esri and is used herein under license. Copyright (C) 2021 Esri and its licensors. All rights reserved. Hwy, Highway; I-182, Interstate Highway 182.

\section{Fish Monitoring Array}

A total of 11 fixed monitoring sites were established to detect tagged fish moving within the study area. All monitoring sites contained radio telemetry equipment and were located downstream from Roza Dam on the Yakima River and downstream from Priest Rapids Dam on the Columbia River (fig. 2). Monitoring sites on the Yakima River were located in the tailrace of Roza Dam (rkm 205.8), at Sunnyside Dam (rkm 167.0), at Marion Drain near Granger, Washington (rkm 132.6), at Prosser Dam (rkm 75.5), at the confluence of Spring and Snipes Creeks and the Yakima River (rkm 67.1), at Chandler Outfall (rkm 57.6), at the confluence of Corral Creek and the Yakima River (rkm 53.9), at Wanawish Dam (rkm 29.0), and at the I-182 Bridge (rkm 7.5). Monitoring sites on the Columbia River were located approximately 16.2 rkm upstream from the mouth of the Yakima River at Johnson Island (rkm 555.2) and approximately $7.0 \mathrm{rkm}$ downstream from the mouth of the Yakima River at the Highway 395 Bridge in Kennewick, Washington (rkm 532). Sites in the Yakima River were operated continuously from June 19 to October 21, 2020. Sites in the Columbia River were operated continuously from June 16 to October 26, 2020.

Mobile tracking was conducted to collect additional information on the location of tagged fish in the study area between fixed sites. A vehicle was used to slowly drive along the river, where feasible, while monitoring for the presence of tagged fish. In the lower Yakima River and Columbia River, a boat was used to conduct mobile tracking. When a tagged fish was observed, the date, time, and coordinates (latitude and longitude) of the detection location were recorded. Mobile tracking was conducted 3-4 times per month during the study period. If the mobile tracking crew encountered a tag that was not moving, they attempted to locate the tag to determine the fate of the fish. A final effort to locate and recover tags in the Yakima River was attempted at the end of the study period.

\section{Data Analysis}

Detection records from fixed monitoring sites were merged with tagging and release records to create a preliminary dataset. The preliminary dataset then was integrated with mobile tracking records to create a draft dataset that was proofed using an automated program to remove non-valid detection records. Records were determined to be non-valid if (1) they occurred prior to release, (2) the signal strength was less than the 90th percentile of the signal strength of detections of tag identification codes that were not released during the study (noise), (3) less than three consecutive detections occurred at a given monitoring station (consecutive detections had to be 60 seconds or less apart), and (4) it was impossible for the detection to occur geographically (for example, detections at separate locations with timestamps that would have exceeded the swimming capability of the fish). These criteria were used in the automated program to remove nonvalid detection records from the dataset containing detections of study fish. The auto-proofed dataset then was manually reviewed to confirm that the auto-proofing process was successful and to verify that the dataset could be considered final for analysis. This final dataset was used for all data queries and analyses presented in this report. 


\section{Environmental Conditions}

We used data collected at existing streamgages in the Yakima River to describe water temperature and river flow patterns during the study. Daily water temperature data from the U.S. Geological Survey (USGS) streamgage located on the Yakima River at the Van Giesen Bridge in Richland, Washington (about rkm 13.5; USGS streamgage 12511800) were downloaded for the June 1, 2020-October 1, 2020 time period from the following site: https://waterdata.usgs.gov/ wa/nwis/uv/?site_no $=12511800 \& P A R A m e t e r$. Data at this streamgage were not available after October 1, 2020. Daily water temperature data from the USGS streamgage located on the Columbia River at Pasco, Washington (USGS streamgage 12514400) were downloaded for June 1, 2020-October 1, 2020 from the following site: https://waterdata.usgs.gov/wa/ nwis/uv/?site_no $=12514400 \&$ agency_cd $=$ USGS. Historical water temperature data from 2013 to 2020 were downloaded from USGS streamgage 12514400 and the Reclamation streamgage on the Yakima River in the Chandler fish screen weather station (about rkm 46) from the following site: https://www.usbr.gov/pn-bin/yak/webarccsv.pl?station= CFSW \&year $=2013 \&$ month $=6 \&$ day $=1 \&$ year $=2020 \&$ month $=$ $10 \&$ day $=1 \&$ pcode $=W Z$. Daily river flow data from the Reclamation streamgage on the Yakima River in the Prosser Dam tailrace (about rkm 75.6) were downloaded for June 1, 2020-October 1, 2020 from the following site: https://www .usbr.gov/pn-bin/yak/webarccsv.pl?station=YRPW\&year= $2019 \&$ month $=6 \&$ day $=1 \&$ year $=2019 \&$ month $=10 \&$ day $=$ $31 \&$ pcode $=Q D$. Diel periods were assigned using civil twilight at Prosser, Washington, downloaded at https://sunrisesunset.org/us/prosser-wa/2020/10.

\section{Fish Behavior}

\section{Radio-Tagged Fish}

We examined the final dataset to describe the behavior of tagged fish and movements using six reaches of the study area (table 3). Final locations of fish were determined from a combination of fixed and mobile detections, PIT detections, transmitter temperature data, and tag recoveries. We queried detection records to determine if there was evidence that fish used cool water refugia during their migration. To do this, we first calculated residence times of tagged fish at all sites including known areas of cool water inputs at Spring and Snipes Creeks, Chandler Outfall, Corral Creek, and I-182 Bridge sites. Residence times were determined by subtracting the time of first detection at each site from the time of last detection at that same site. If a fish made multiple trips past a site (a trip is defined as detection at a site after being detected at another site or detection at the same site after an absence of detections for greater than 1 hour), then the time spent at the site during the multiple trips also was included in the residence time (that is, it was possible for one fish to have multiple trips at a site). If fish used these sites as cool water refugia, we would expect to see extended residence times at those sites. Data from 2019 were included for comparison (Kock and others, 2020). Diel periods using civil twilight were assigned to each detection. Radio transmitters that were recovered were downloaded to obtain water temperature data records. These records were merged with detections from fixed monitoring sites and mobile tracking to determine individual fish locations at specific times during the temperature history.

\section{Passive Integrated Transponder-Tagged Fish}

Tagging and detection history data of PIT-tagged adult sockeye released in the Columbia River Basin were downloaded from the PTAGIS website (https://www.ptagis.org/) on January 15,2021 . The percentage of tagged fish that moved upstream from Prosser Dam and arrived at Roza Dam was calculated by dividing the number of fish detected in the fish ladder at Roza Dam by the number of tagged fish detected in fish ladders at Prosser Dam. Travel time was calculated as the elapsed time between the last detection at Prosser Dam and the first detection at Roza Dam. Diel periods were assigned using civil twilight at Prosser, Washington.

Table 3. Study reach descriptions used in this report.

\begin{tabular}{ll}
\hline \multicolumn{1}{c}{ Reach name } & \multicolumn{1}{c}{ Reach description } \\
\hline Downstream from McNary Dam & Columbia River, downstream from McNary Dam. \\
McNary Dam to Yakima River mouth & Columbia River, from the forebay of McNary Dam to the Yakima River mouth. \\
Snake River & Snake River, upstream from Ice Harbor Dam. \\
Yakima River & Yakima River, upstream from the Yakima River mouth. \\
Hanford Reach & Columbia River, from the mouth of the Yakima River to the tailrace of Priest Rapids Dam. \\
Upstream from Priest Rapids Dam & Columbia River, upstream from Priest Rapids Dam. \\
\hline
\end{tabular}




\section{Results}

\section{Environmental Conditions}

Water temperature in the lower Yakima River exceeded $20{ }^{\circ} \mathrm{C}$ most days from mid-June to early September and peaked at $28^{\circ} \mathrm{C}$ on July 31, 2020 (fig. 3). River flows were about 700 cubic feet per second $\left(\mathrm{ft}^{3} / \mathrm{s}\right)$ on the first day of tagging and remained at less than $1,000 \mathrm{ft}^{3} / \mathrm{s}$ on most days until mid-October. Flow peaked in the fall on October 27, 2020 at $3,270 \mathrm{ft}^{3} / \mathrm{s}$. Columbia River water temperature was less than $20^{\circ} \mathrm{C}$ during most of the study period. In mid-September, Yakima River water temperatures cooled and decreased to less than Columbia River water temperatures for the remainder of the study (fig. 3).

\section{Fish Behavior}

\section{Radio-Tagged Sockeye Salmon Released at Prosser Dam}

Radio-tagged sockeye salmon released in the forebay of Prosser Dam initially moved upstream and spread out in the Prosser Dam-to-Sunnyside Dam reach. A total of six tagged fish (46 percent) were detected at Marion Drain and two fish (15 percent) were detected at Sunnyside Dam. However, all fish stopped moving within 2 weeks of release and several transmitters were recovered in the Prosser Dam-to-Sunnyside Dam reach. Thermal history data from those transmitters were plotted along with Columbia River and Yakima River water temperature and detection events (app. 1, figs. 1.1-1.6). One transmitter was recovered approximately $100 \mathrm{~m}$ upstream in Sulphur Drain (rkm 98), which enters the Yakima River near Sunnyside, Washington; one transmitter was recovered near the Chandler Fish Handling Facility (rkm 75); one transmitter was recovered $8 \mathrm{rkm}$ downstream from Sunnyside Dam (rkm 159); two transmitters were recovered $16 \mathrm{rkm}$ downstream from Sunnyside Dam (near Buena, Washington, rkm 151); and one transmitter was recovered in the tailrace of John Day Dam. None of the recovered tags were located inside or near a carcass at the time of recovery. Temperature data from the tag collected near the Chandler Fish Handling Facility were consistent with the internal body temperature of a bird, which suggests that the fish had been consumed by an avian predator (app. 1, fig. 1.2) and presumably was transported downstream to the recovery site by the bird. Similarly, based on a combination of radiotelemetry and temperature data, another fish was detected near Prosser Dam for three days and then transported to the tailrace of John Day Dam, presumably by an avian predator (app. 1, fig. 1.6). The PIT tag of a third fish (tagged on June 20) was recovered at the Badger Island avian colony on the Columbia River, upstream from McNary Dam. Temperature records and detections from fixed sites indicated that at least three other tagged fish were consumed by avian predators for a total of 6 fish out of the 144 adult sockeye salmon tagged during the study. These six fish were last detected at Marion Drain (1 fish), Spring and Snipes Creek (1 fish), Chandler Fish Handling Facility (1 fish), and Prosser Dam (3 fish). None of the tagged fish released at Prosser Dam were detected upstream from Sunnyside Dam.

\section{Radio-Tagged Sockeye Salmon Released at Yakima River Mouth}

Sixteen of the 19 radio-tagged sockeye salmon released at the mouth of the Yakima River were detected at radiotelemetry or PIT-tag monitoring sites. Of those 16 fish, two fish were detected downstream from McNary Dam, four fish were detected between McNary Dam and the mouth of the Yakima River, two fish were detected in the Yakima River, 15 fish were detected in the Hanford Reach, and two fish were detected upstream from Priest Rapids Dam. Of the fish that moved upstream to the Hanford Reach, all were detected at the Johnson Island site within 1-4 days after tagging. Twelve of those fish made multiple trips to Johnson Island and two were detected at Priest Rapids Dam. One of the fish detected at Priest Rapids Dam eventually moved upstream and was detected at Rock Island Dam.

The last known locations of radio-tagged fish included two fish downstream from McNary Dam in John Day Reservoir, two fish in the Yakima River, two fish near the mouth of the Yakima River, nine fish in the Hanford Reach, and one fish upstream from Priest Rapids Dam (table 4). One fish, released at the mouth of the Yakima River on June 20, 2020, moved upstream into the Hanford Reach, was detected in the fish ladder at Priest Rapids Dam, and then moved downstream, passed McNary Dam, and was harvested in John Day Reservoir (fig. 4). Two fish, tagged and released on August 7, were detected at the Johnson Island site in the Hanford Reach and then later entered the Yakima River when the water temperature was $16-18{ }^{\circ} \mathrm{C}$ (fig. 5). One fish moved upstream to Sunnyside Dam and stopped; the transmitter was recovered there on October 26, 2020 (fig. 6). The other fish moved upstream to Prosser Dam and then back downstream. Its transmitter was recovered upstream from Wanawish Dam on October 22, 2020 (fig. 7). Three radio-tagged fish released at the mouth of the Yakima River were never detected during the study (two from the June release; one from the August release).

Detection records were plotted to show the relation between diel arrival period (daytime versus nighttime) and residence time at fixed telemetry sites within the study area (fig. 8). These data were plotted along with results from the 2019 study (Kock and others, 2020) to provide a summary of multi-year residence times at fixed telemetry sites to-date (fig. 8). Most tagged fish spent less than 10 hours at fixed sites in the study area during both years. Sites where extended residence (greater than 20 hours) occurred included Sunnyside Dam, Prosser Dam, Chandler Outfall, and Wanawish Dam (fig. 8). 


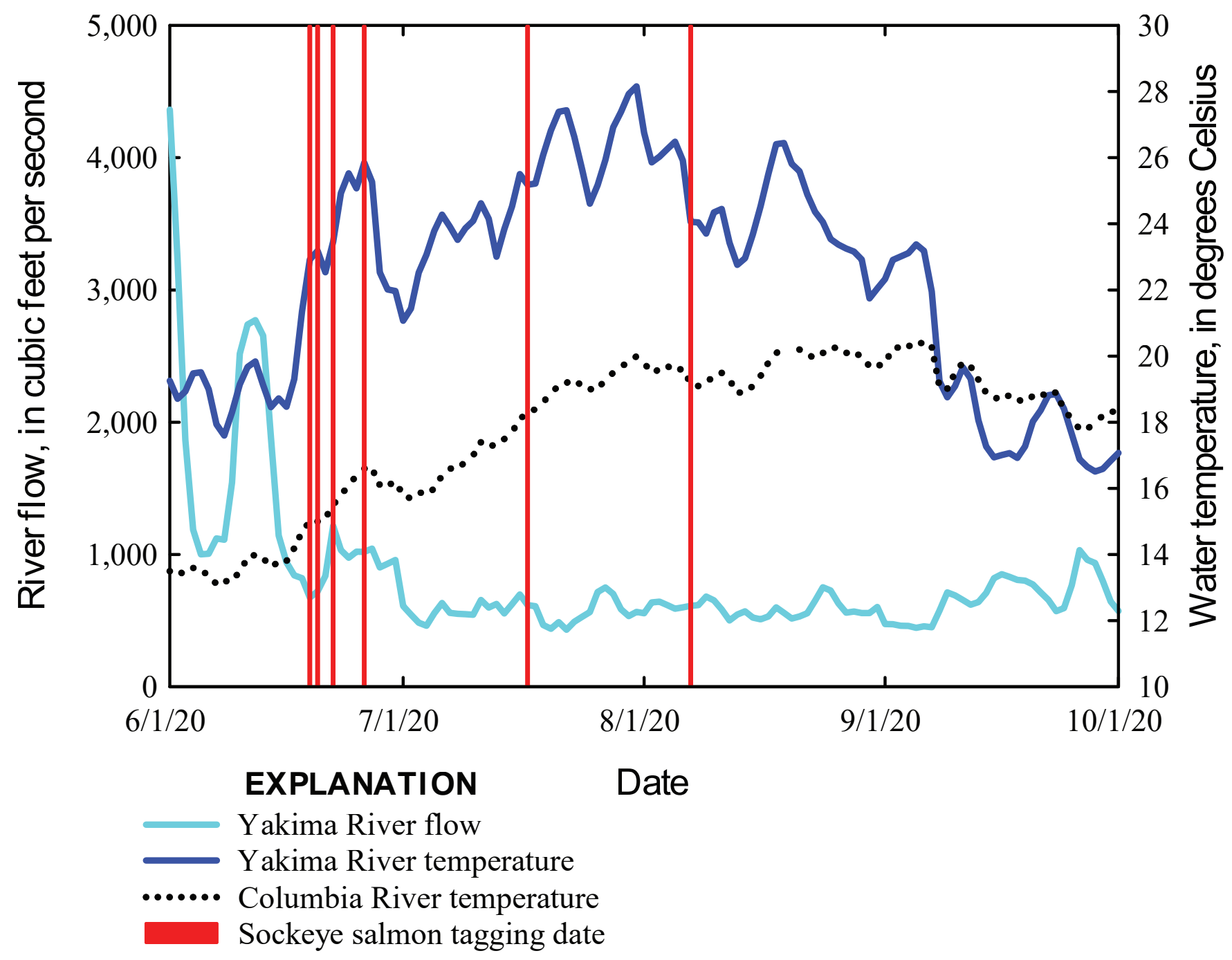

Figure 3. Sockeye salmon tagging dates (red vertical lines), mean daily river flow in the Yakima River (light blue line), mean daily water temperature in the lower Yakima River (dark blue line), and mean daily water temperature in the Columbia River (black dotted line) near Richland, Washington, June 1-0ctober 1, 2020. 
Table 4. Final locations of radio- and passive integrated transponder-tagged adult sockeye by release month after collection and release at the mouth of the Yakima River, Washington, 2020.

[Detection history: Downstream from McNary Dam (Columbia River river kilometer [rkm] 0 to 470); McNary Dam to Yakima River mouth (Columbia River rkm 470 to 539); Snake River (Snake River rkm 0 to 173); Yakima River (Yakima River rkm 0 to 206); Hanford Reach (Columbia River rkm 539 to 639); Upstream from Priest Rapids Dam (Columbia River upstream from rkm 639); Avian predation, which includes PIT-tag recovery at Badger Island in the Columbia River (rkm 512). PIT: Passive integrated transponder-tagged; no., number of fish. RT+PIT: Passive integrated transponder plus radio telemetry transmitter-tagged]

\begin{tabular}{|c|c|c|c|c|c|c|c|c|}
\hline \multirow[b]{2}{*}{ Detection history } & \multicolumn{2}{|c|}{ June } & \multicolumn{2}{|c|}{ July } & \multicolumn{3}{|c|}{ August } & \multirow{2}{*}{$\begin{array}{c}\text { Combined } \\
\text { Total } \\
\text { (percent) }\end{array}$} \\
\hline & $\begin{array}{l}\text { PIT } \\
\text { (no.) }\end{array}$ & $\begin{array}{c}\text { Total } \\
\text { (percent) }\end{array}$ & $\begin{array}{l}\text { PIT } \\
\text { (no.) }\end{array}$ & $\begin{array}{c}\text { Total } \\
\text { (percent) }\end{array}$ & RT+PIT & $\begin{array}{c}\text { PIT } \\
\text { (no.) }\end{array}$ & $\begin{array}{c}\text { Total } \\
\text { (percent) }\end{array}$ & \\
\hline $\begin{array}{l}\text { McNary Dam to Yakima } \\
\text { River mouth }\end{array}$ & 0 & $0(0)$ & 0 & $0(0)$ & 1 & 1 & $2(3)$ & $2(2)$ \\
\hline Yakima River & 6 & $6(50)$ & 11 & $11(29)$ & 2 & 24 & $26(38)$ & $43(36)$ \\
\hline Hanford Reach & 0 & $0(0)$ & 1 & $1(3)$ & 1 & 1 & $2(3)$ & $3(2)$ \\
\hline $\begin{array}{l}\text { Upstream from Priest } \\
\text { Rapids Dam }\end{array}$ & 2 & $2(17)$ & 7 & $7(18)$ & 1 & 5 & $6(9)$ & $15(13)$ \\
\hline Avian predation & 0 & $0(0)$ & 1 & $1(3)$ & 0 & 1 & $1(1)$ & $2(2)$ \\
\hline
\end{tabular}




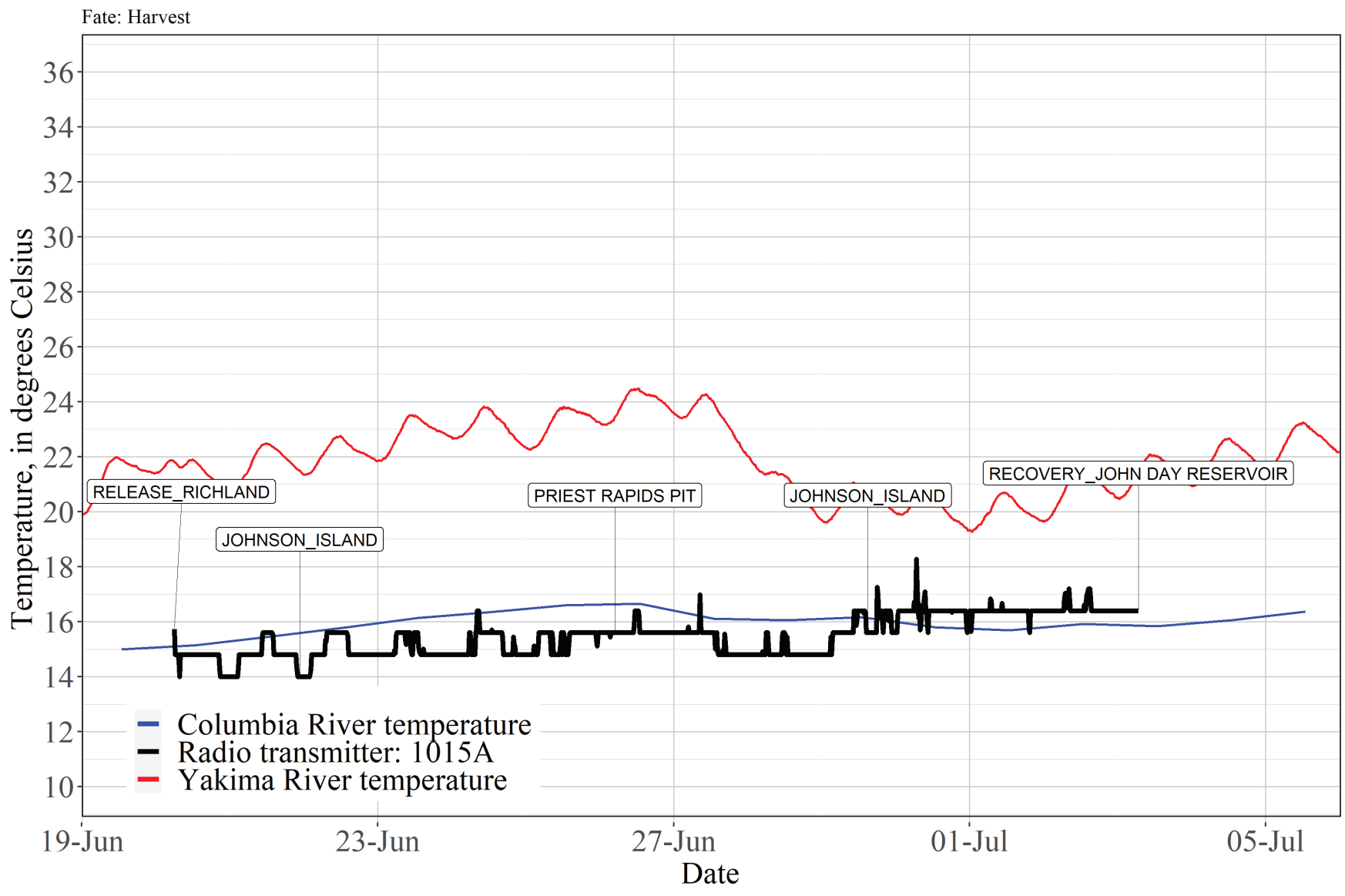

Figure 4. Water temperature use data (thick black line) collected by a radio transmitter inside an adult sockeye salmon (fork length 48 centimeters) released at the mouth of the Yakima River on June 20, 2020. The fish was harvested in John Day Reservoir on July 8, 2020. Black text boxes identify times and locations of detection in the study area. Water temperature data from the Columbia River (blue line; streamgage PAOW, Pasco, Washington) and Yakima River (red line; streamgage CFSW; Chandler Fish Screens) are included for reference. PIT, passive integrated transponder. 


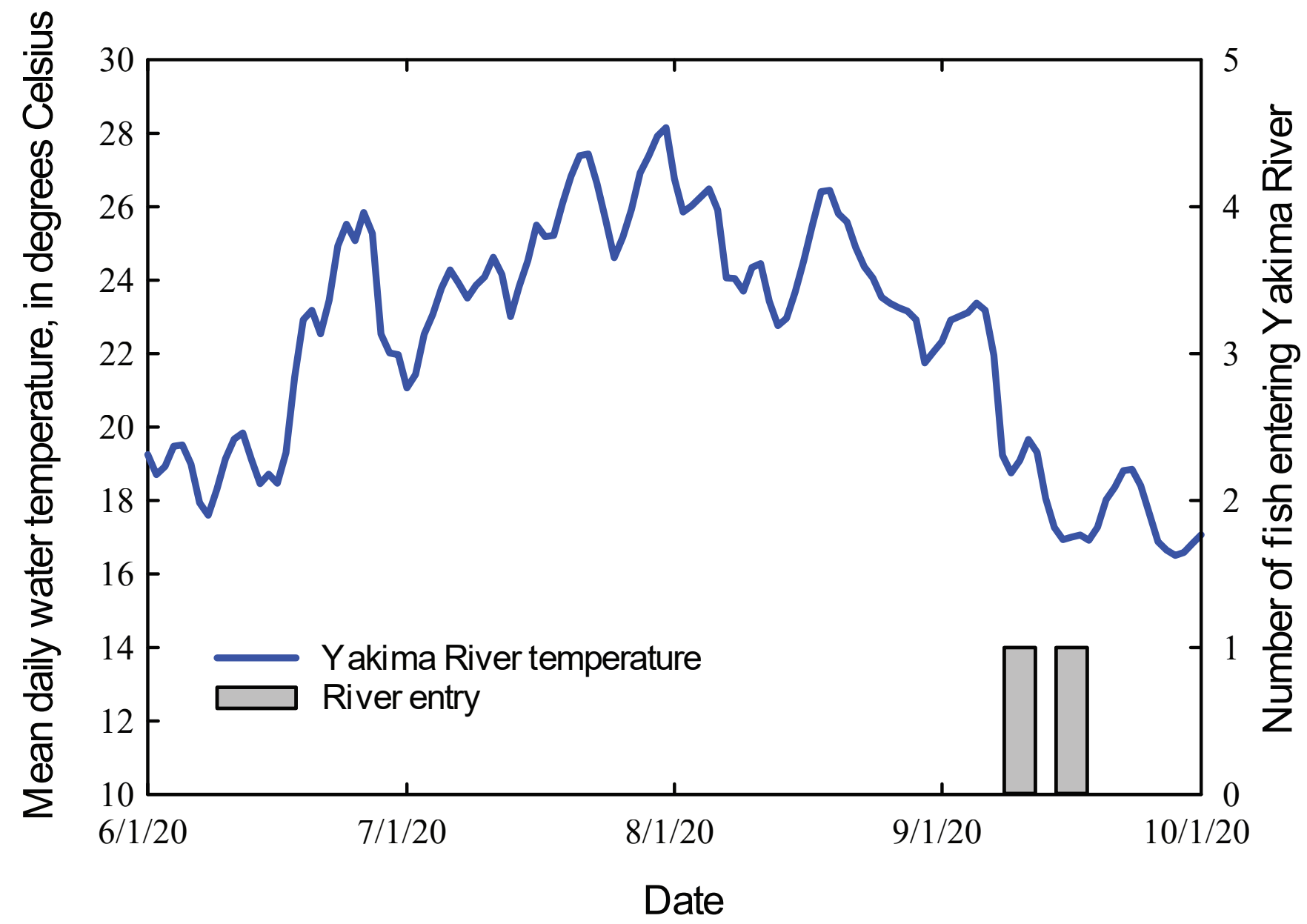

Figure 5. Mean daily water temperature as measured at the Van Giesen Bridge (U.S. Geological Survey streamgage 12511800) in Richland, and number of radio-tagged sockeye salmon that entered the Yakima River and were detected on a fixed site, Washington, 2020. 


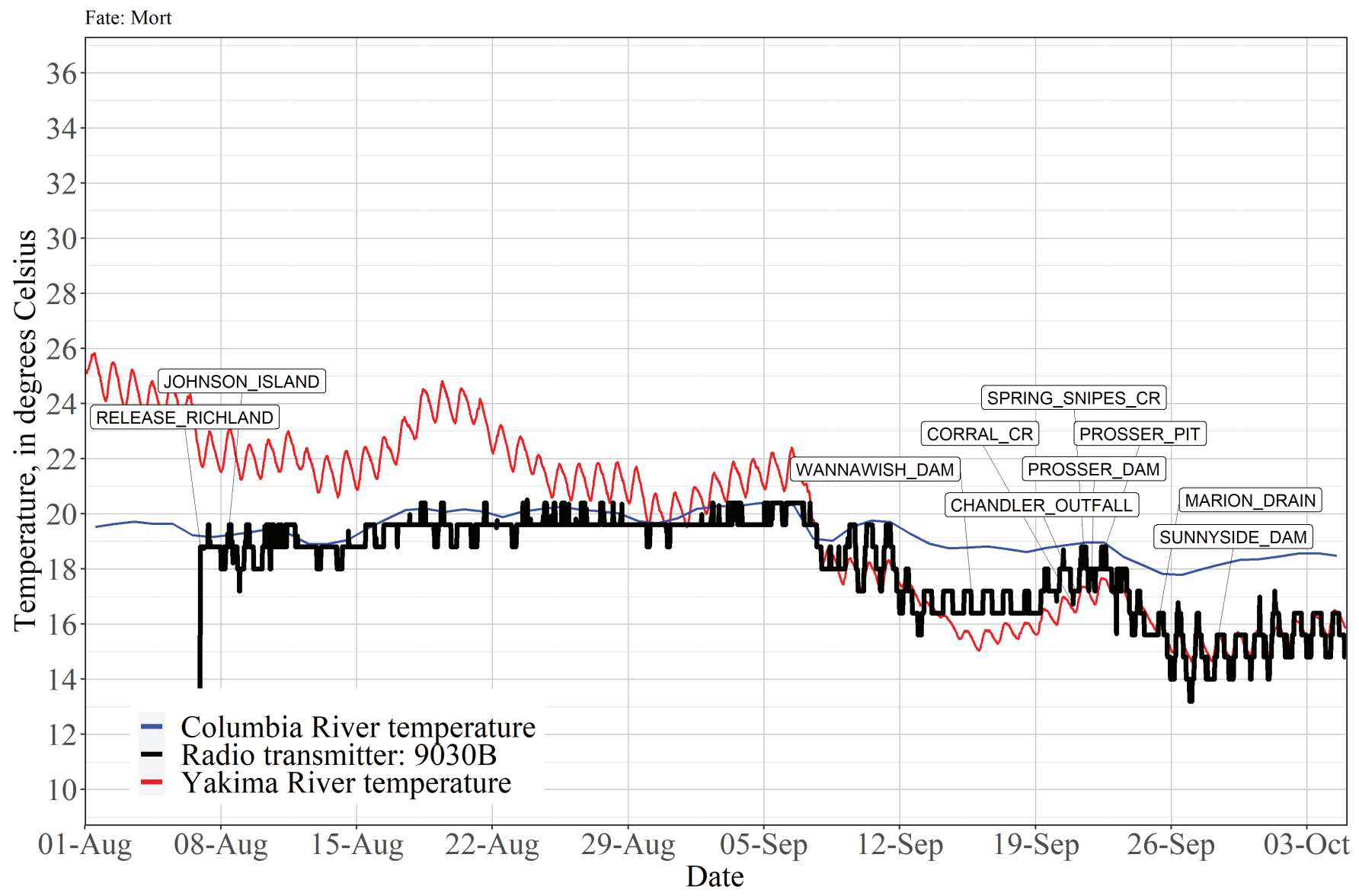

Figure 6. Water temperature use data (thick black line) collected by a radio transmitter inside an adult sockeye salmon (fork length 49 centimeters) released at the mouth of the Yakima River on August 7, 2020. The transmitter was recovered near Sunnyside Dam on October 26, 2020. Black text boxes identify times and locations of detection in the study area. Water temperature data from the Columbia River (blue line; streamgage PAOW, Pasco, Washington) and Yakima River (red line; streamgage CFSW; Chandler Fish Screens) are included for reference. CR, Creek; PIT, passive integrated transponder. 


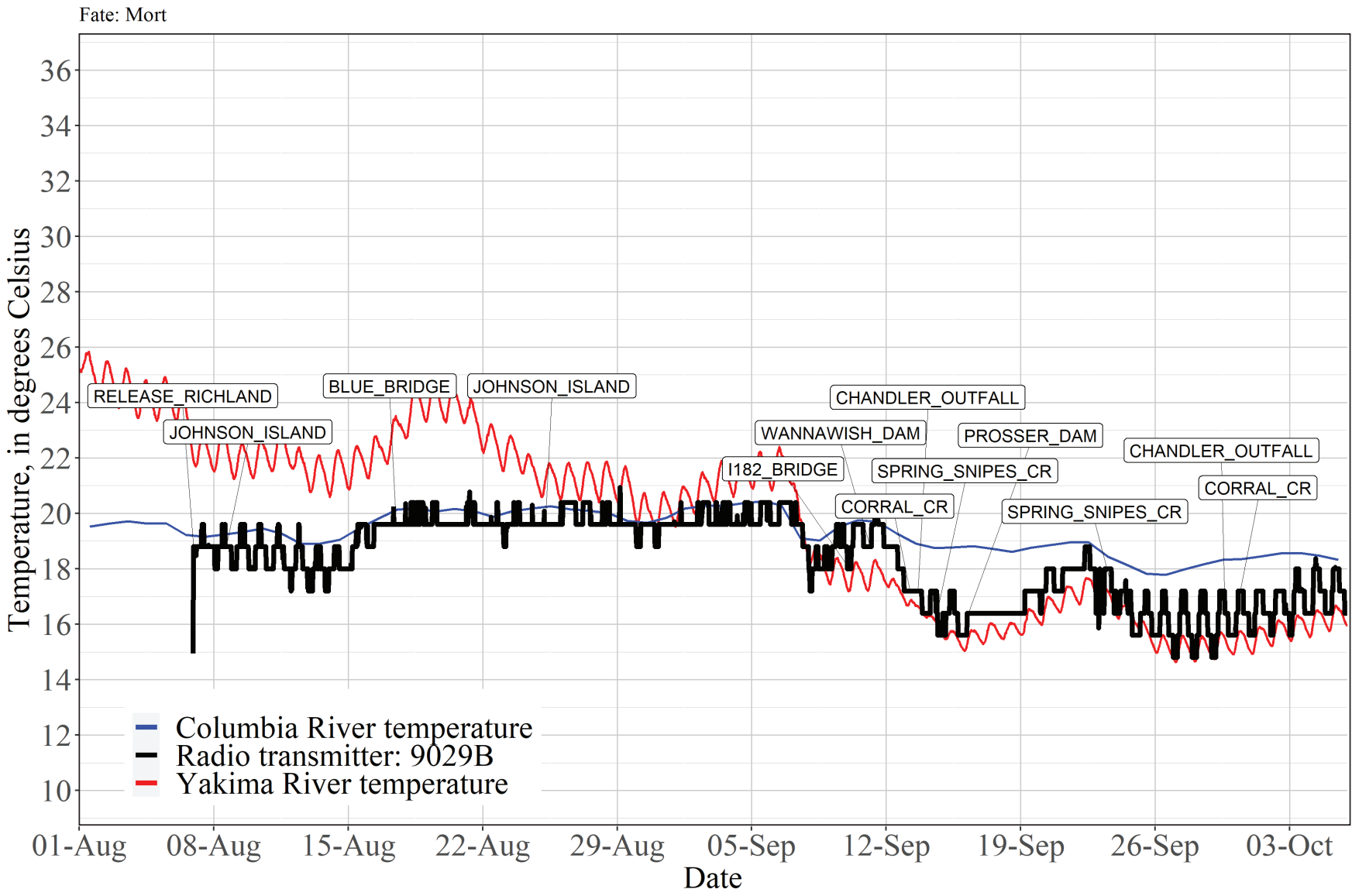

Figure 7. Water temperature use data (thick black line) collected by a radio transmitter inside an adult sockeye salmon (fork length 53 centimeters) released at the mouth of the Yakima River on August 7, 2020. The transmitter was recovered near Benton City, Washington, on October 22, 2020. Black text boxes identify times and locations of detection in the study area. Water temperature data from the Columbia River (blue line; streamgage PAOW, Pasco, Washington) and Yakima River (red line; streamgage CFSW; Chandler Fish Screens) are included for reference. CR, Creek. 


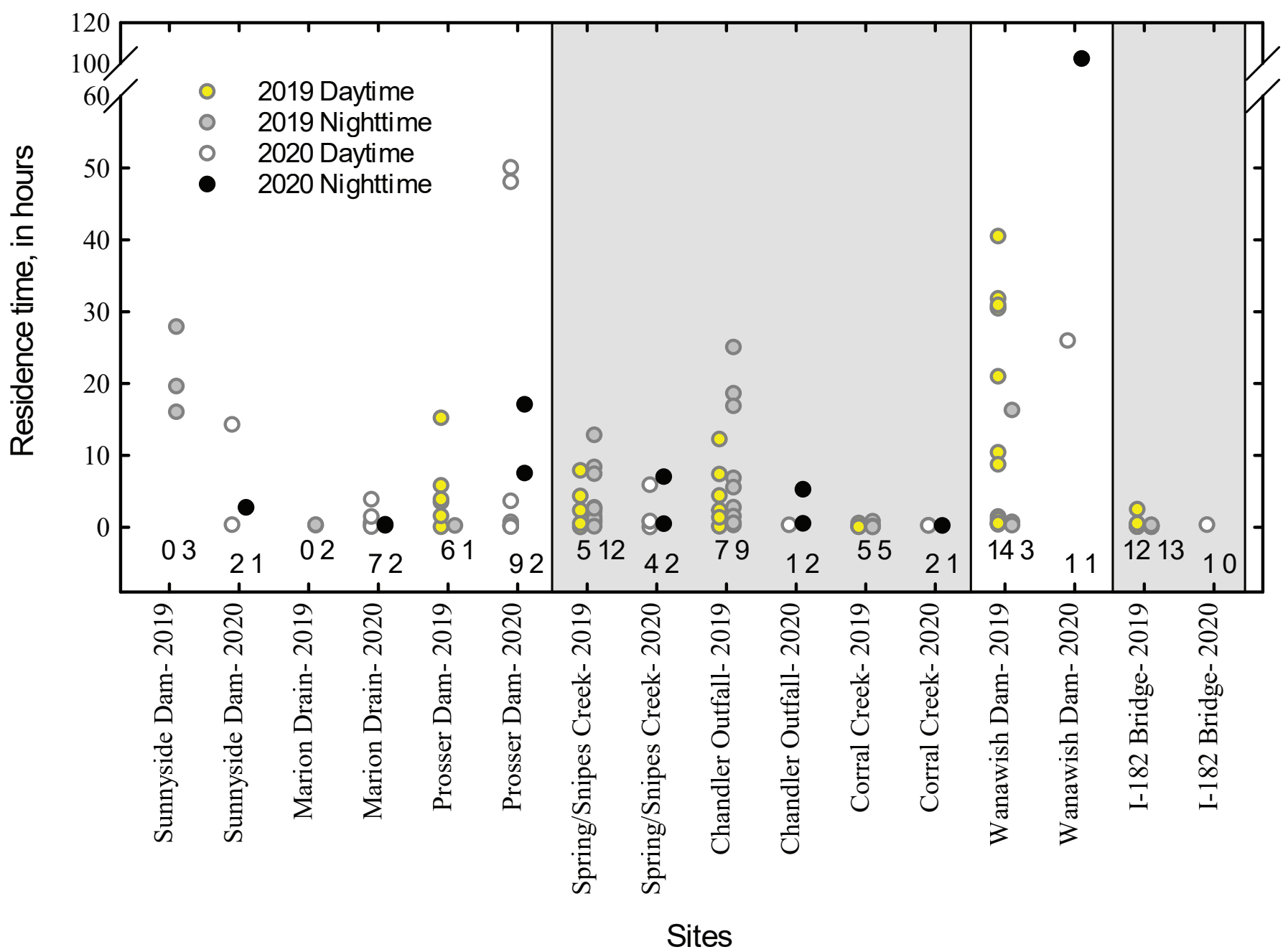

Figure 8. Residence time by diel arrival period for radio-tagged adult sockeye salmon at fixed telemetry sites on the lower Yakima River, Washington, 2019-20. Diel period is defined by civil twilight and potential cool water sites are shaded gray. Multiple trips of fish are included, and total number of trips are shown below the data points for each site.

\section{Passive Integrated Transponder-Tagged Sockeye Salmon Released at Yakima River Mouth}

A total of 112 adult sockeye salmon were PIT-tagged and released at the mouth of Yakima River in June (12 fish), July (38 fish), and August (62 fish) 2020. Sixty-one (54 percent) of the PIT-tagged sockeye salmon eventually were detected on PIT-tag antennas in the Yakima, Columbia, and Snake Rivers (table 5). Detection locations included Three Mile Falls Dam on the Umatilla River; McNary Dam on the Columbia River; Ice Harbor Dam on the Snake River; Yakima River; Ringold Springs Hatchery, Priest Rapids Hatchery and Dam, Rock Island Dam, Rocky Reach Dam, and Wells Dam on the upper Columbia River; and the Wenatchee River including Tumwater Dam. The largest percentage of tagged fish from monthly release groups were detected in the Yakima River (50 percent of June-released fish; 29 percent of July-released fish; 37 percent of August-released fish; table 5).

Based on location of last detection of the 112 PIT-tagged sockeye salmon, 37 percent of the fish (41 fish) entered the Yakima River, 14 percent (16 fish) moved upstream in the Columbia River, 2 percent (2 fish) moved downstream from McNary Dam, and 46 percent (51 fish) were not detected (table 5). Two PIT tags were recovered at Badger Island, which presumably was the result of avian predation. The final location of the combined total of 61 detected PIT-tagged fish was predominantly in the Yakima River (67 percent) and was highest after release in June and August (fig. 9). A total of 26 percent of PIT-tagged fish were last detected in the Columbia River at Priest Rapids or upstream. 
Table 5. Detection history of passive integrated transponder-tagged adult sockeye salmon released at the mouth of the Yakima River in river reaches by chronological detection history and release month, Washington, 2020.

[Detection history: Downstream from McNary Dam (Columbia River rkm 0 to 470); McNary Dam to Yakima River mouth (Columbia River kilometer [rkm] 470 to 539); Snake River (Snake River rkm 0 to 173); Yakima River (Yakima River rkm 0 to 206); Hanford Reach (Columbia River rkm 539 to 639); Upstream from Priest Rapids Dam (Columbia River upstream from rkm 639); Avian predation, which includes passive integrated transponder-tag recovery at Badger Island in the Columbia River (rkm 512)]

\begin{tabular}{|c|c|c|c|c|}
\hline \multirow{2}{*}{ Detection history } & \multicolumn{4}{|c|}{ Number of fish detected } \\
\hline & June & July & August & Total \\
\hline Avian predation & 0 & 1 & 1 & 2 \\
\hline McNary Dam to Yakima River mouth to the main-stem Yakima River & 0 & 0 & 1 & 1 \\
\hline McNary Dam to Yakima River mouth & 0 & 0 & 1 & 1 \\
\hline Upstream from Priest Rapids Dam to the Snake River to upstream from Priest Rapids Dam & 0 & 1 & 0 & 1 \\
\hline Upstream from Priest Rapids Dam & 2 & 6 & 5 & 13 \\
\hline No detection & 4 & 17 & 30 & 51 \\
\hline Total & 12 & 38 & 62 & 112 \\
\hline
\end{tabular}
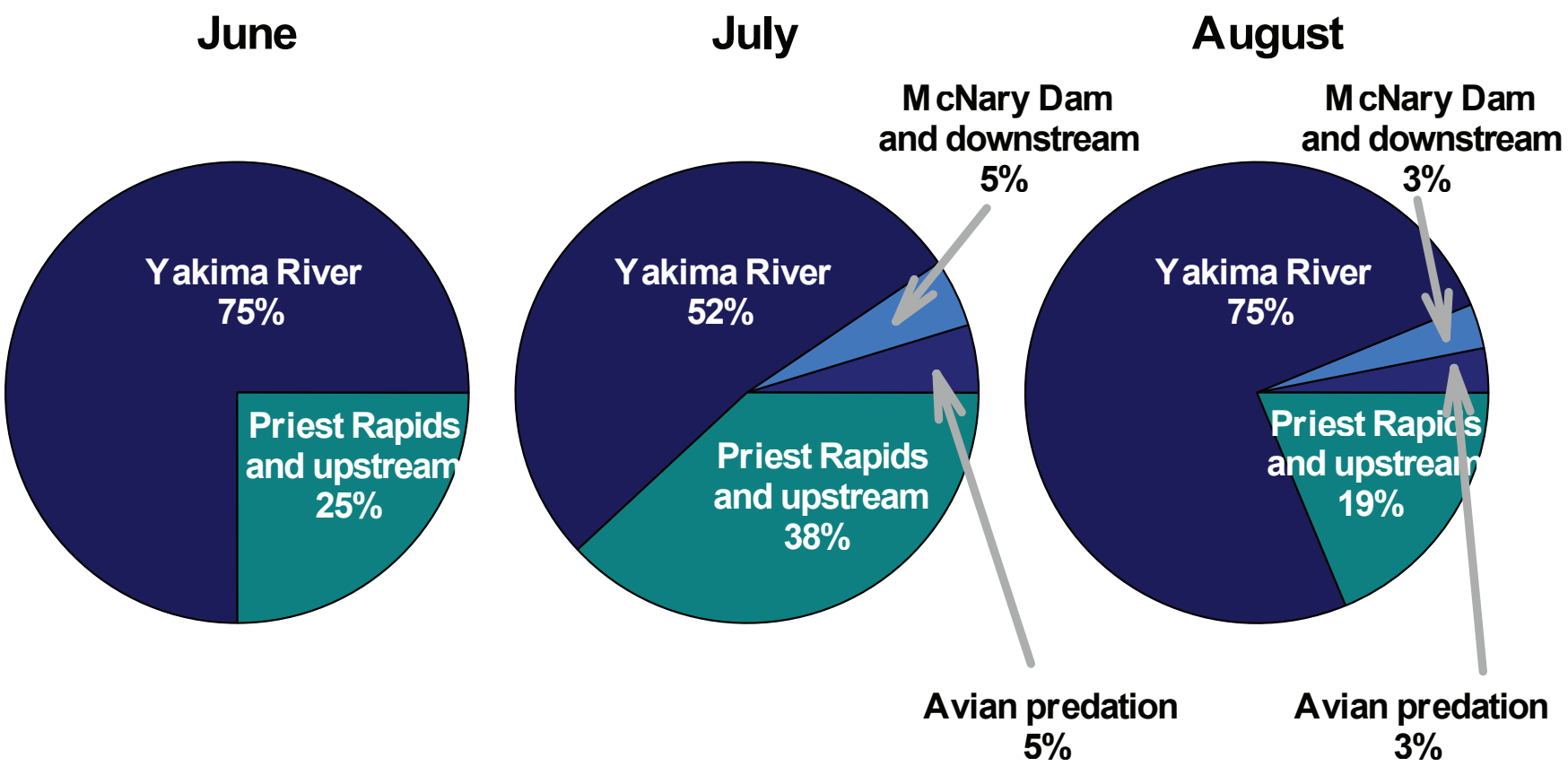

Figure 9. Percentages of detected passive integrated transponder-tagged adult sockeye salmon at final locations by release month after release at the mouth of the Yakima River, Washington, 2020. \%, percent. 
During 2020, a total of 56 PIT-tagged sockeye salmon were detected in the Yakima River after tagging and release at Bonneville Dam (14 fish), the mouth of the Yakima River (41 fish), and Priest Rapids Dam (1 fish). Upstream movement by PIT-tagged fish in the Yakima River occurred primarily during early July and September (fig. 10). Most (63 percent) PITtagged fish arrived at Prosser Dam during daylight hours, but many fish (21 percent) arrived just after sunset (figs. 11-12). Fifty-five percent (31 of 56) of the PIT-tagged fish that passed Prosser Dam eventually moved upstream and were detected at Roza Dam (table 6; fig. 13), including 21 of the fish released at the mouth of the Yakima River. Median travel time from Prosser Dam to Roza Dam was 9.1 days (range $=6.0-41.2$ days).

\section{Water Temperature Use}

Tagged sockeye salmon experienced a range of temperatures in the Yakima and Columbia Rivers. Fish released at Prosser Dam experienced water temperatures in the Yakima River ranging from 16 to $24^{\circ} \mathrm{C}$ in June and $10-22^{\circ} \mathrm{C}$ in July (app. 1, figs. 1.1-1.6). Fish released at the mouth of the Yakima River and detected in the Columbia River encountered water temperatures ranging from 17 to $21{ }^{\circ} \mathrm{C}$ in June and July (fig. 4), and $19-21^{\circ} \mathrm{C}$ in August and early September (figs. 6-7). September and October water temperatures in the Yakima River cooled from 19 to $15^{\circ} \mathrm{C}$ (figs. 6-7).
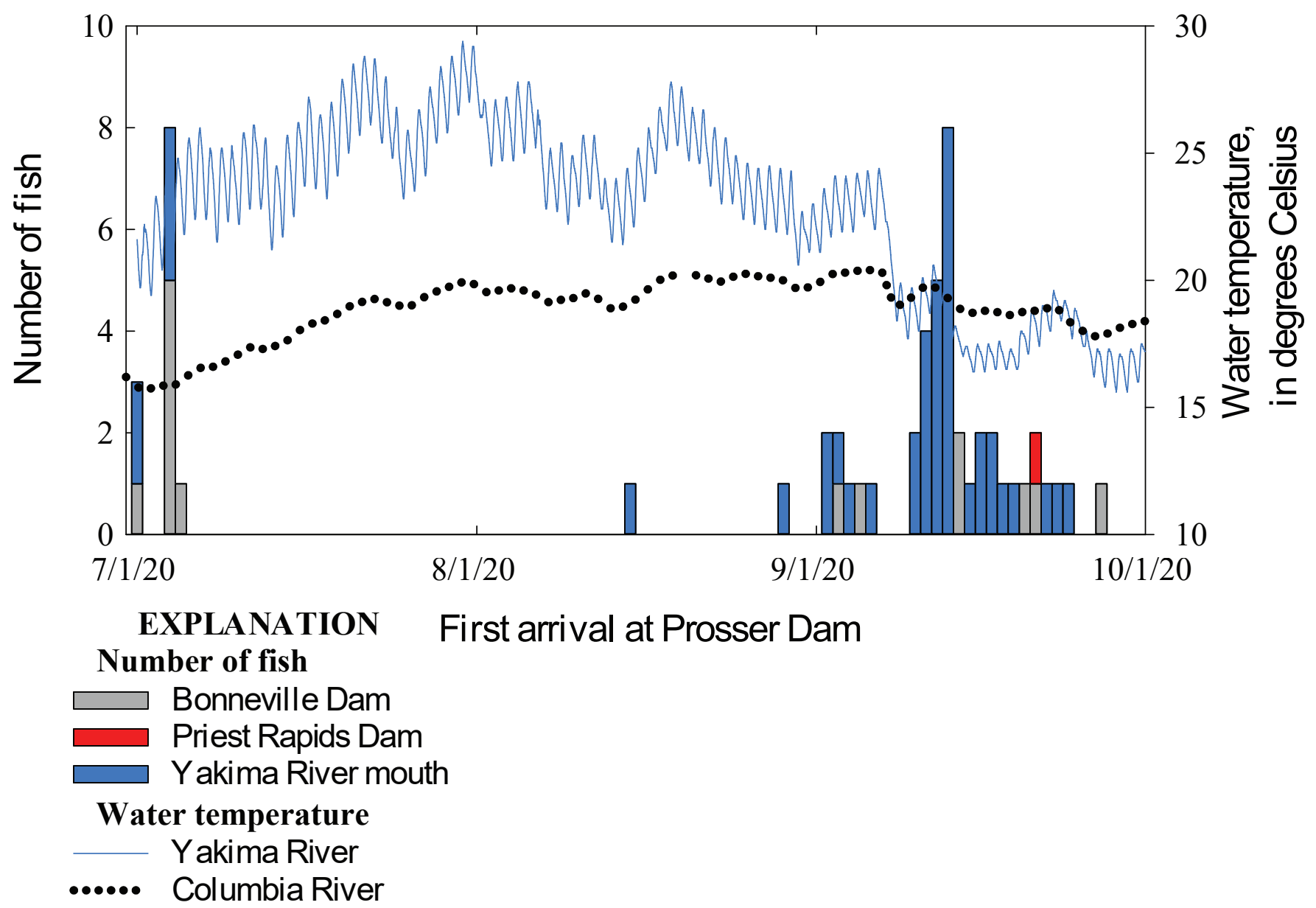

Figure 10. Number of passive integrated transponder-tagged sockeye salmon arriving at Prosser Dam by date in the Yakima River after tagging at Bonneville Dam (number of fish $[n]=14)$, the mouth of the Yakima River ( $n=41)$, and Priest Rapids Dam ( $n=1)$, Washington, 2020. 


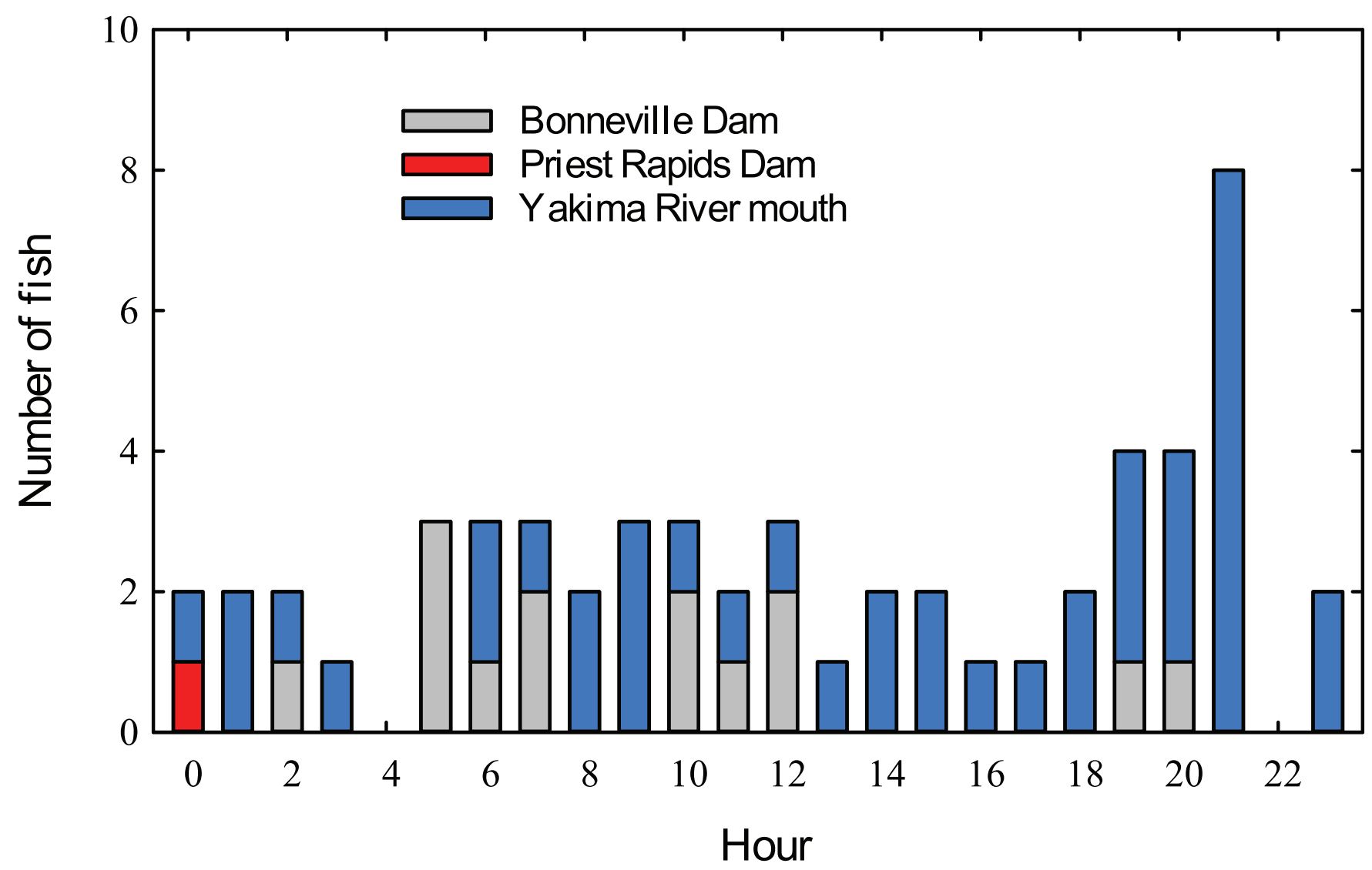

Figure 11. Hour of first arrival of passive integrated transponder-tagged sockeye salmon at Prosser Dam in the Yakima River, after tagging at Bonneville Dam (number of fish $[n]=14)$, the mouth of the Yakima River $(n=41)$, and Priest Rapids Dam (n=1), Washington, 2020. 


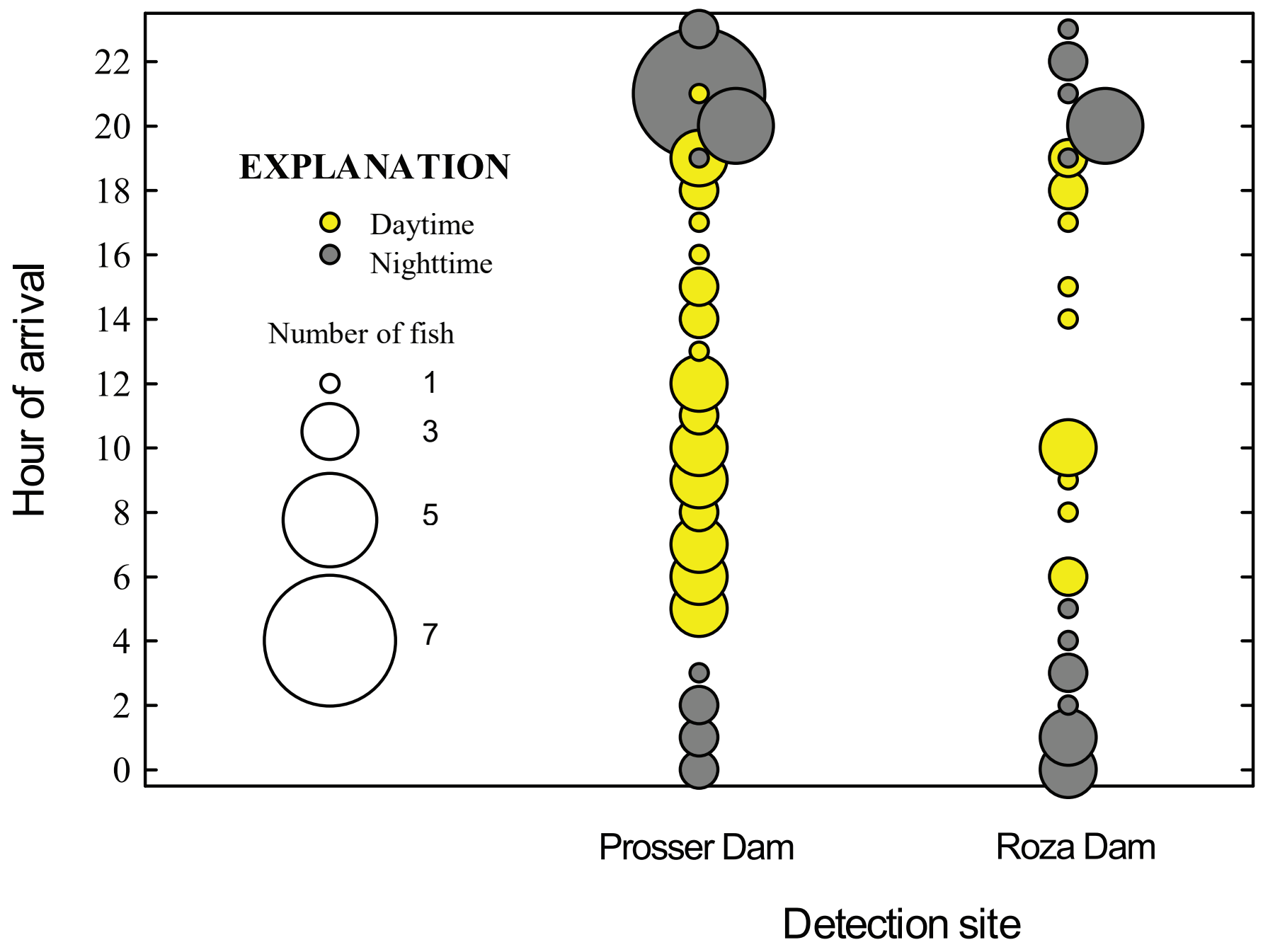

Figure 12. Hour of passive integrated transponder-tagged sockeye salmon arrival at Prosser and Roza Dams in the Yakima River, Washington, 2020. The size of circles is proportional to the number of fish represented in each value. Fish were tagged at Bonneville Dam (number of fish $[n]=14)$, the mouth of the Yakima River $(n=41)$, and Priest Rapids Dam $(n=1)$. 
Table 6. Number of passive integrated transponder-tagged sockeye salmon detected at Prosser and Roza Dams in the Yakima River, and the percentage of fish that successfully arrived at Roza Dam after passing Prosser Dam (percentage successful), by week of arrival at Prosser Dam, Washington, 2020.

[Tagged fish were released at the Bonneville and Priest Rapids Dams, and at the mouth of the Yakima River. mm-dd-yy, month-day-year]

\begin{tabular}{ccccc}
\hline $\begin{array}{c}\text { From } \\
\text { (mm-dd-yy) }\end{array}$ & $\begin{array}{c}\text { To } \\
\text { (mm-dd-yy) }\end{array}$ & $\begin{array}{c}\text { Detected at } \\
\text { Prosser Dam }\end{array}$ & $\begin{array}{c}\text { Detected at } \\
\text { Roza Dam }\end{array}$ & $\begin{array}{c}\text { Percentage } \\
\text { successful }\end{array}$ \\
\hline $07-01-20$ & $07-07-20$ & 12 & 9 & 75 \\
$07-08-20$ & $07-14-20$ & 0 & 0 & 0 \\
$07-15-20$ & $07-21-20$ & 0 & 0 & 0 \\
$07-22-20$ & $07-28-20$ & 0 & 0 & 0 \\
$07-29-20$ & $08-04-20$ & 0 & 0 & 0 \\
$08-05-20$ & $08-11-20$ & 0 & 0 & 0 \\
$08-12-20$ & $08-18-20$ & 1 & 1 & 100 \\
$08-19-20$ & $08-25-20$ & 0 & 0 & 0 \\
$08-26-20$ & $09-01-20$ & 1 & 0 & 0 \\
$09-02-20$ & $09-08-20$ & 7 & 3 & 43 \\
$09-09-20$ & $09-15-20$ & 21 & 17 & 81 \\
$09-16-20$ & $09-22-20$ & 11 & 1 & 9 \\
$09-23-20$ & $09-29-20$ & 3 & 0 & 0 \\
\hline
\end{tabular}

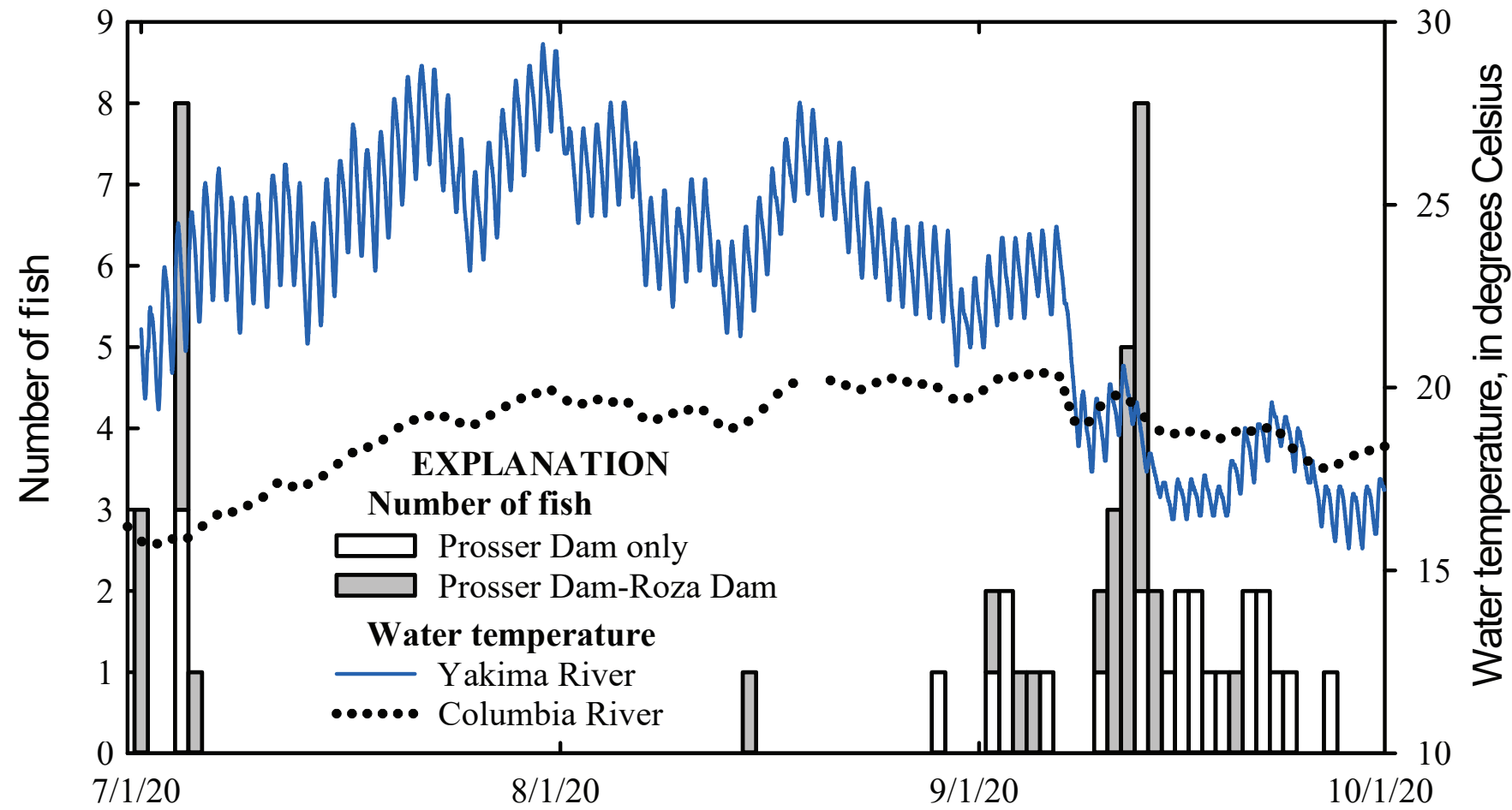

First arrival at Prosser Dam

Figure 13. Number of adult passive integrated transponder-tagged sockeye released in the Columbia River Basin that only were detected at Prosser Dam (open boxes) and both Prosser and Roza Dams (shaded boxes), Washington. Water temperature in the Yakima River is plotted on the right $y$-axis. Detected fish were released at Bonneville Adult Fish Facility (number of fish [ $n]=14$ ), Priest Rapids $\operatorname{Dam}(n=1)$, and the mouth of the Yakima River $(n=41)$. 


\section{Discussion}

Results from this and other studies suggest that a substantial number of sockeye salmon destined for the Yakima River fail to reach Roza Dam where they are collected and transported upstream from Cle Elum Dam for spawning. We found that only 21 of the 144 (15 percent) sockeye salmon tagged and released during this study eventually moved upstream in the Yakima River and arrived at Roza Dam. During our 2019 study, a total of 60 sockeye salmon were tagged and released in the Yakima River and at the mouth of the Yakima River but only 1 tagged fish was collected at Roza Dam (Kock and others, 2019). Other studies have reported similar results. Hess and others (2021) used genetic parentage analysis to identify fish of Yakima River origin from among sockeye salmon sampled at Bonneville Dam, and estimated that 11,719 sockeye salmon adults from the Yakima River passed Bonneville Dam in 2020. However, catch data from Roza Dam showed that only 4,379 sockeye salmon were subsequently collected. Among the 31 PIT-tagged fish that were assigned genetically to the Yakima River, most (27 fish; 87 percent) were detected passing McNary Dam, but only 4 of those (13 percent) were detected in the Yakima River, and 11 (35 percent) of the fish that failed to enter the Yakima River were never detected after passing McNary Dam. Because these fish were not detected on PIT-tag antennas located at Prosser, Priest Rapids, and Ice Harbor Dams, or at other upstream detection sites, we presume that the 11 PIT-tagged fish last detected at McNary Dam remained in the Columbia River between McNary and Priest Rapids Dams, in the Yakima River downstream from Prosser Dam, or in the Snake River downstream from Ice Harbor Dam. The 51 PIT-tagged fish that went undetected after collection, tagging, and release at the mouth of the Yakima River during our study had a fate similar to the fate of the fish in the Bonneville sample.

These findings support the hypothesis that elevated summer water temperatures create a thermal block that negatively affects the migration of Yakima River sockeye salmon. Existing data show that Yakima River sockeye salmon largely are absent from the lower Yakima River during summer when the water temperature exceeds $20^{\circ} \mathrm{C}$. However, during this time, many fish destined for the Yakima River are present in the Columbia River at the mouth of the Yakima River. After experiencing the thermal block of the Yakima River for an extended period, some of these fish eventually move to other Columbia River subbasins prior to the onset of spawning. The inhibited migration associated with higher water temperatures is consistent with movement barriers we observed between fixed tracking sites. Specifically, the probability of a fish reaching the adult trap at Roza Dam decreases when the passage date at Prosser Dam moves later into the summer, until September when water temperatures begin to drop. Passage counts for sockeye salmon adults at Prosser Dam are very low when water temperature is greater than $20^{\circ} \mathrm{C}$ in the lower
Yakima River. Additionally, telemetry results have shown that tagged fish moved downstream and out of the Yakima River during periods of increasing water temperature, and only reentered the river when it cooled to $20^{\circ} \mathrm{C}$ or less (Kock and others, 2019). Detections of tagged fish were common near the mouth of the Yakima River during the summer, and the largest proportion of PIT-tagged fish from groups released in June, July, and August 2020 eventually were detected in the Yakima River. These results indicate that Yakima River sockeye salmon spent considerable time near the mouth of the Yakima River waiting for water temperature to cool and thereby facilitate or stimulate upstream migration. Detections of some Yakima River fish that were PIT-tagged at Bonneville Dam (Hess and others, 2021) or tagged at the mouth of the Yakima River included last-known locations in the Upper Columbia River, Ringold Springs Fish Hatchery, and the Umatilla River, approximately $70 \mathrm{rkm}$ downstream. Finally, results from 2020 showed that only 61 percent of the PIT-tagged sockeye salmon detected at Prosser Dam successfully moved upstream to Roza Dam, and that most fish that failed to arrive at Roza Dam passed Prosser Dam in mid-to-late September.

Results from the study confirmed that piscivorous birds consume adult sockeye salmon during upstream migration in the Yakima and Columbia Rivers. We determined that at least 6 of the 13 radio-tagged sockeye salmon released in the Prosser Dam forebay were consumed by piscivorous birds. The transmitter from one of these fish was recovered in the tailrace of John Day Dam, which indicates that the fish was consumed in the Prosser Dam-to-Sunnyside Dam reach and transported to the Columbia River, and that the transmitter was deposited at the recovery location. Although we were able to confirm that piscivorous birds consumed radio-tagged fish upstream from Prosser Dam, we do not know if the fish were alive and healthy, sick, or dead at the time of consumption. Other data sources provide additional information about bird consumption as well. Several PIT tags from adult sockeye salmon tagged in 2020 at Bonneville and Priest Rapids Dams, and the mouth of the Yakima River were recovered on islands with bird colonies where fish predation has been documented (Evans, Payton, and others, 2016). Although adult sockeye salmon are relatively large, American white pelicans (Pelecanus erythrorhynchos) and double-crested cormorants (Phalacrocorax auritus) have been shown to consume Lost River suckers (Deltistes luxatus) and shortnose suckers (Chasmistes brevirostris) as large as 730 millimeters (Evans, Hewitt, and others, 2016). In addition to tagging data that confirm consumption by piscivorous birds, we also observed several adult sockeye salmon in the trap at Prosser Dam that had fresh wounds on the dorsal side of their bodies (fig. 14). We believe that these wounds resulted from attempted predation events by American white pelicans as fish migrated upstream in the Yakima River. Additional research will be required to better understand the magnitude of adult sockeye salmon consumption by piscivorous birds. 


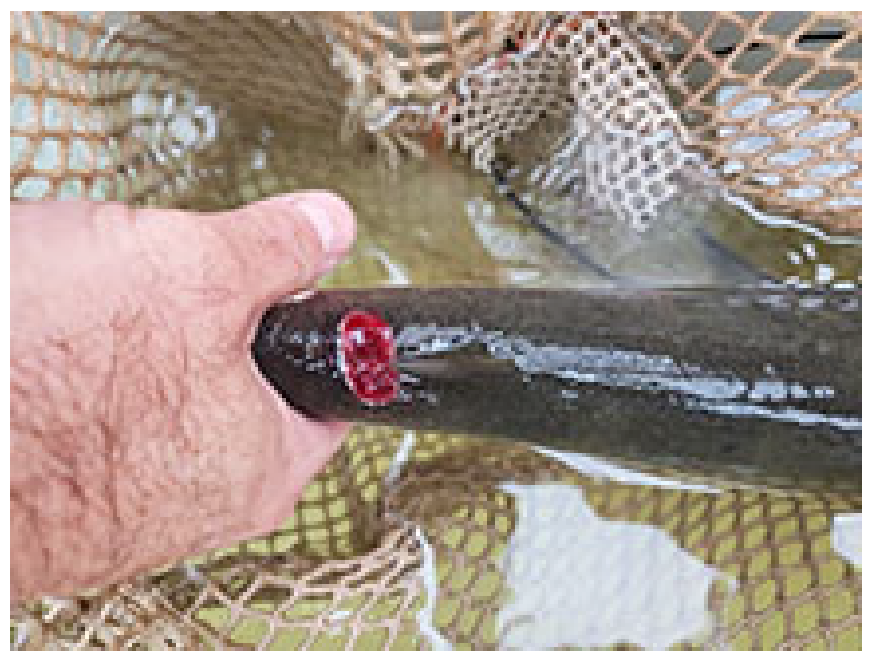

Figure 14. Dorsal wound on an adult sockeye salmon trapped for radio-tagging at Prosser Dam, Washington, on June 26, 2019. Photograph by Tobias J. Kock, U.S. Geological Survey.

Growing evidence suggests that diversion dams alter migration behavior by adult sockeye salmon in the Yakima River. Residence times at most telemetry monitoring sites were low (less than 5 hours) during 2019 and 2020, but extended residence times (greater than 24 hours) were observed at Sunnyside, Prosser, and Wanawish Dams. Thus, migration behavior in the lower Yakima River seems to consist of rapid upstream movements that are delayed when fish encounter diversion dams. A study conducted on the upper Yakima River in 2018 (Kock and others, 2019) indicated similar results in which tagged sockeye salmon spent less than 2 hours at fixed sites with the exception of Town Ditch (a diversion dam near Ellensburg, Washington) where median residence time was 19.7 hours. In our 2019 and 2020 studies on the lower Yakima River, we observed several fish that moved upstream to Prosser Dam, where upstream movement stopped, and the fish eventually began moving downstream (Kock and others, 2020). This behavior occurred during September and October, which is when sockeye salmon begin spawning in the Yakima Basin (Matala and others, 2019), so these fish likely were in poor condition and physically incapable of moving upstream and passing several diversion dams. Future studies will be required to better understand how diversion dams affect migration of adult sockeye salmon in the Yakima River.

Finally, data collected during 2019 and 2020 suggest that sockeye salmon primarily migrate past cool water sites in the lower Yakima River and spend little time holding at these locations. Although observations are limited to a low number of tagged fish, residence times at cool water sites have been consistently low during the 2 years of study. Future research using techniques such as snorkeling and underwater videography would be helpful. These approaches would allow researchers to identify and quantify fish species present at these sites during periods when summer water temperature exceeds $20^{\circ} \mathrm{C}$. This information would be useful for better understanding the relative importance of these sites during summer, and for potentially designing studies to collect additional information.

\section{References Cited}

Appel, M., Little, R., Wendt, H., and Nielson, M., 2011, Assessment of the lower Yakima River in Benton County, Washington: Report by the Benton County Conservation District to the Salmon Recovery Funding Board, 182 p., accessed October 2019, at https://ybfwrb.org/wp-content/ uploads/2017/10/Lower_Yakima_Assessment.pdf.

Bureau of Reclamation, 2005, Phase I assessment reportStorage dam fish passage study, Yakima Project, Washington: Bureau of Reclamation Technical Series No. PN-YDFP-001, 75 p. plus appendixes. [Also available at https://www.usbr.gov/pn/studies/fishpassage/phase1/entiredoc.pdf.]

Bureau of Reclamation, 2011, Cle Elum and Bumping Lake Dams fish passage facilities planning report-Storage dams fish passage study, Yakima project, Washington: Bureau of Reclamation, 362 p., accessed October 2019, at https://www .usbr.gov/pn/studies/fishpassage/planningreports/dra ftplanningreport.pdf.

Ebersole, J.L., Liss, W.J., and Frissell, C.A., 2001, Relationship between stream temperature, thermal refugia and rainbow trout Oncorhynchus mykiss abundance in aridland streams in the northwestern United States: Ecology Freshwater Fish, v. 10, p. 1-10.

Ebersole, J.L., Liss, W.J., and Frissell, C.A., 2003, Thermal heterogeneity, stream channel morphology, and salmonid abundance in northeastern Oregon streams: Canadian Journal of Fisheries and Aquatic Sciences, v. 60, p. $1266-1280$.

Eliason, E.J., Clark, T.D., Hague, M.J., Hanson, L.M., Gallagher, Z.S., Jeffries, K.M., Gale, M.K., Patterson, D.A., Hinch, S.G., and Farrell, A.P., 2011, Differences in thermal tolerance among sockeye salmon populations: Science, v. 332, p. 109-112. [Also available at https://doi.org/ 10.1126/science.1199158.]

Evans, A.F., Hewitt, D.A., Payton, Q., Cramer, B.M., Collis, K., and Roby, D.D., 2016, Colonial waterbird predation on Lost River and shortnose suckers in the upper Klamath Basin: North American Journal of Fisheries Management, v. 36, p. 1254-1268. [Also available at https://doi.org/ 10.1080/02755947.2016.1208123.]

Evans, A.F., Payton, Q., Turecek, A., Cramer, B., Collis, K., Roby, D.D., Loschl, P.J., Sullivan, L., Skalski, J., Weiland, M., and Dotson, C., 2016, Avian predation on juvenile salmonids - Spatial and temporal analysis based on acoustic and passive integrated transponder tags: Transactions of the American Fisheries Society, v. 145, p. 860-877. [Also available at https://doi.org/10.1080/00028487.2016.1150881.] 
Hatch, D., Ward, A., Porter, A., and Schwartzberg, M., 1993, The feasibility of estimating sockeye salmon escapement at Zosel Dam using underwater video technology-1992 annual progress report-Prepared for Public Utility District No. 1 of Douglas County: Portland, Oregon, Columbia River Inter-Tribal Fish Commission, 27 p.

Hess, J.E., Collins, E.E., Harmon, S.A., Horn, R.L., Kock, I., Stephenson, J., Willis, S., and Narum, S.R., 2021, Genetic assessment of Columbia River stocks, 1/1/2020-12/21/2020 - Annual report, 2008-907-00: Prepared for U.S. Department of Energy Bonneville Power Administration by the Columbia River Inter-Tribal Fish Commission, Portland, Oregon, 329 p.

Hess, M.A., Hess, J.E., Matala, A.P., French, R.A., Steele, C.A., Lovtang, J.C., and Narum, S.R., 2016, Migrating adult steelhead utilize a thermal refuge during summer periods with high water temperatures: ICES Journal of Marine Science, v. 73, p. 2616-2624, https://doi.org/10.1093/ icesjms/fsw 120 .

Jeffries, K.M., Hinch, S.G., Sierocinski, T., Clark, T.D., Eliason, E.J., Donaldson, M.R., Li, S., Pavlidis, P., and Miller, K.M., 2012, Consequences of high temperatures and premature mortality on the transcriptome and blood physiology of wild adult sockeye salmon (Oncorhynchus nerka): Ecology and Evolution, v. 2, p. 1747-1764. [Also available at https://doi.org/10.1002/ece3.274.]

Keefer, M.L., Peery, C.A., and Heinrich, M.J., 2008, Temperature-mediated en route migration mortality and travel rates of endangered Snake River sockeye salmon: Ecology Freshwater Fish, v. 17, no. 1, p. 136-145. [Also available at https://doi.org/10.1111/j.16000633.2007.00267.x.]

Keefer, M.L., Peery, C.A., Ringe, R.R., and Bjornn, T.C., 2004, Regurgitation rates of intragastric radio transmitters by adult Chinook salmon and steelhead during upstream migration in the Columbia and Snake Rivers: North American Journal of Fisheries Management, v. 24, p. 47-54.
Kock, T.J., Evans, S.D., Ekstrom, B.K., and Hansen, A.C., 2019, Adult sockeye salmon (Oncorhynchus nerka) behavior and movement from Roza Dam to Cle Elum Dam, Washington, 2018: U.S. Geological Survey OpenFile Report 2019-1053, 8 p., https://doi.org/10.3133/ ofr20191053.

Kock, T.J., Evans, S.D., Hansen, A.C., Ekstrom, B.K., Visser, R., Saluskin, B., and Hoffarth, P., 2020, Evaluation of water temperature effects on adult sockeye salmon (Oncorhynchus nerka) behavior in the Yakima River, Washington, 2019: U.S. Geological Survey Open-File Report 2020-1033, 15 p., https://doi.org/10.3133/ofr20201033.

Macdonald, J.S., Foreman, M.G., Farrell, A.P., Williams, I.V., Grout, J., Cass, A., Woodey, J.C., Enzenhofer, H., Clarke, W.C., Houtman, R., Donaldson, E.M., and Barnes, D., 2000, The influence of extreme water temperatures on migrating Fraser River sockeye salmon (Oncorhynchus nerka) during the 1998 spawning season: Canadian Technical Reports of Fisheries and Aquatic Sciences, v. 2326, 117 p.

Major, R.L., and Mighell, J.L., 1967, Influence of Rocky Reach Dam and the temperature of the Okanogan River on the upstream migration of sockeye salmon: Fish Bulletin, v. 66, p. 131-147.

Martins, E.G., Hinch, S.G., Patterson, D.A., Hague, M.J., Cooke, S.J., Miller, K.M., Robichaud, D., English, K.K., and Farrell, A.P., 2012, High river temperature reduces survival of sockeye salmon (Oncorhynchus nerka) approaching spawning grounds and exacerbates female mortality: Canadian Journal of Fisheries and Aquatic Sciences, v. 69, no. 2, p. 330-342. [Also available at https://doi.org/10.1139/ f2011-154.]

Matala, A.P., Narum, S.R., Saluskin, B.P., Johnston, M.V., Newell, J.E., Fast, D.E., and Galbreath, P.F., 2019, Early observations from monitoring a reintroduction programReturn of sockeye salmon to a nursery lake of historical importance: Transactions of the American Fisheries Society, v. 148, p. 271-288. [Also available at https://doi.org/ 10.1002/tafs.10133.] 
Mathes, T.M., Hinch, S.G., Cooke, S.J., Crossin, G.T., Patterson, D.A., Lotto, A.G., and Farrell, A.P., 2010, Effect of water temperature, timing, physiological condition, and lake thermal refugia on migrating adult Weaver Creek sockeye salmon (Oncorhynchus nerka): Canadian Journal of Fisheries and Aquatic Sciences, v. 67, no. 1, p. 70-84. [Also available at https://doi.org/10.1139/F09-158.]

National Oceanic and Atmospheric Administration, 2016, 2015 Adult sockeye salmon passage report: National Oceanic and Atmospheric Administration Fisheries, 62 p. plus appendixes, accessed December 21, 2020, at https ://archive.fisheries.noaa.gov/wcr/publications/hydropower/ fcrps/2015_adult_sockeye_salmon_passage_report.pdf.

Rand, P.S., Hinch, S.G., Morrison, J., Foreman, M.G.G., MacNutt, M.J., Macdonald, J.S., Healey, M.C., Farrell, A.P., and Higgs, D.A., 2006, Effects of river discharge, temperature, and future climates on energetics and mortality of adult migrating Fraser River sockeye salmon: Transactions of the American Fisheries Society, v. 135, p. 655-667. [Also available at https://doi.org/10.1577/T05-023.1.]
Quinn, T.P., Hodgson, S., and Peven, C., 1997, Temperature, flow, and the migration of adult sockeye salmon (Oncorhynchus nerka) in the Columbia River: Canadian Journal of Fisheries and Aquatic Sciences, v. 54, p. 1349-1360. [Also available at https://doi.org/10.1139/ f97-038.]

U.S. Environmental Protection Agency, 2012, Primer for identifying cold-water refuges to protect and restore thermal diversity in riverine landscapes: U.S. Environmental Protection Agency Report Number 910-C-12-001, 91 p. [Also available online at https://nepis.epa.gov/Exe/ ZyPDF.cgi/P100E45N.PDF?Dockey=P100E45N.PDF.]

Yakama Nation, 1990, Columbia Basin system planning salmon and steelhead production plan, Yakima River subbasin: Confederated Tribes and Bands of the Yakima Indian Nation, 237 p., accessed October 2019, at http://docs.s treamnetlibrary.org/Subbasin_Plans/Columbia_Plateau_ North/Yakima90.pdf. 



\section{Appendix 1. Temperature Use Records from Recovered Transmitters}

Appendix 1 figures show plots of fish detection and water temperature histories of adult sockeye salmon collected using temperature-sensing radio transmitters in the Yakima and Columbia Rivers during 2020.

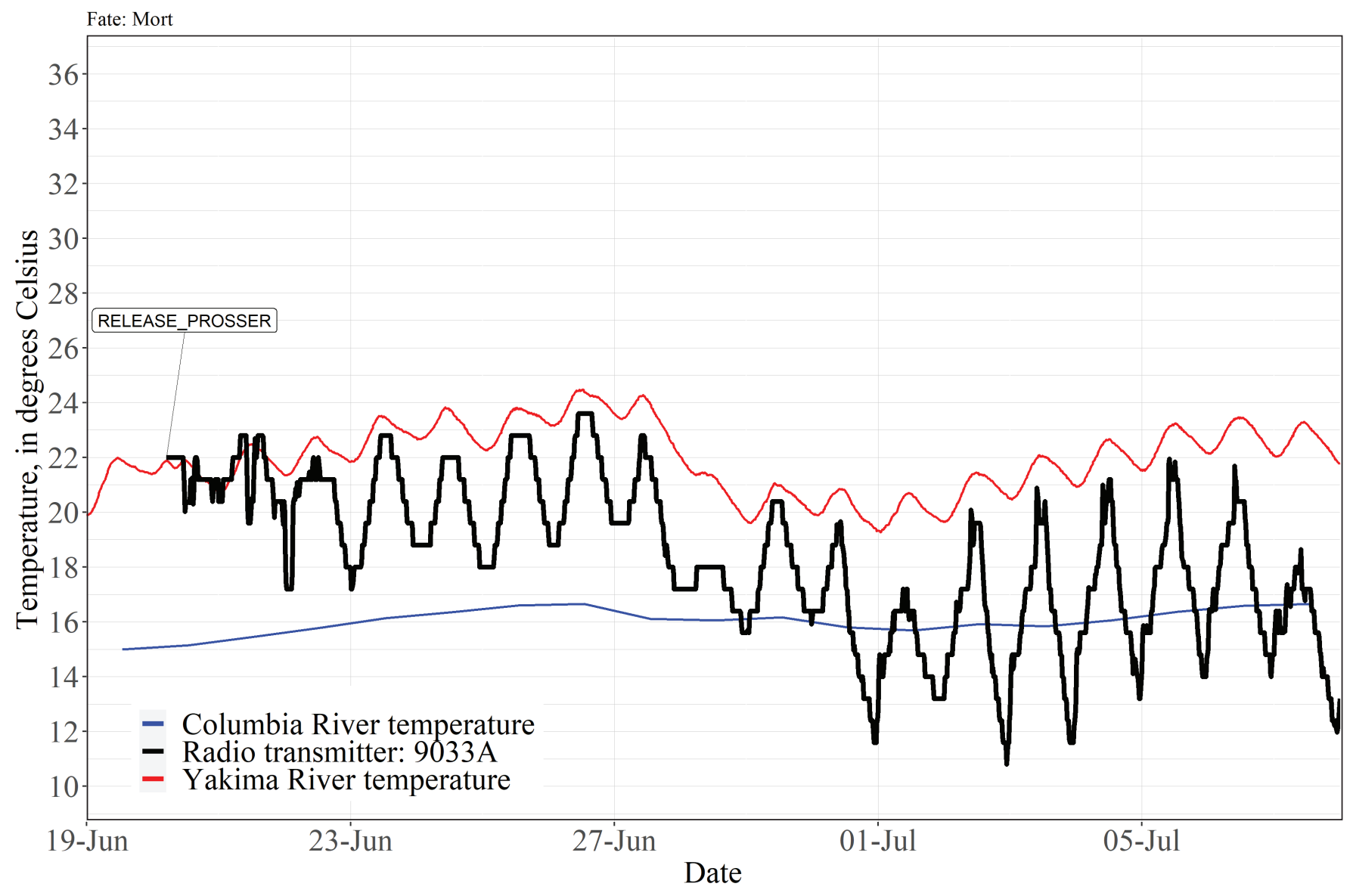

Figure 1.1. Water temperature use data (thick black line) collected by a radio transmitter inside an adult sockeye salmon (fork length 44 centimeters) tagged and released at Prosser Dam on June 20, 2020. Transmitter was recovered approximately 100 meters upstream in Sulphur Drain, which enters the Yakima River near Sunnyside, Washington, on July 8, 2020. Water temperature data from the Columbia River (blue line; streamgage PAOW, Pasco, Washington) and Yakima River (red line; Gage CFSW; Chandler Fish Screens) are included for reference. 


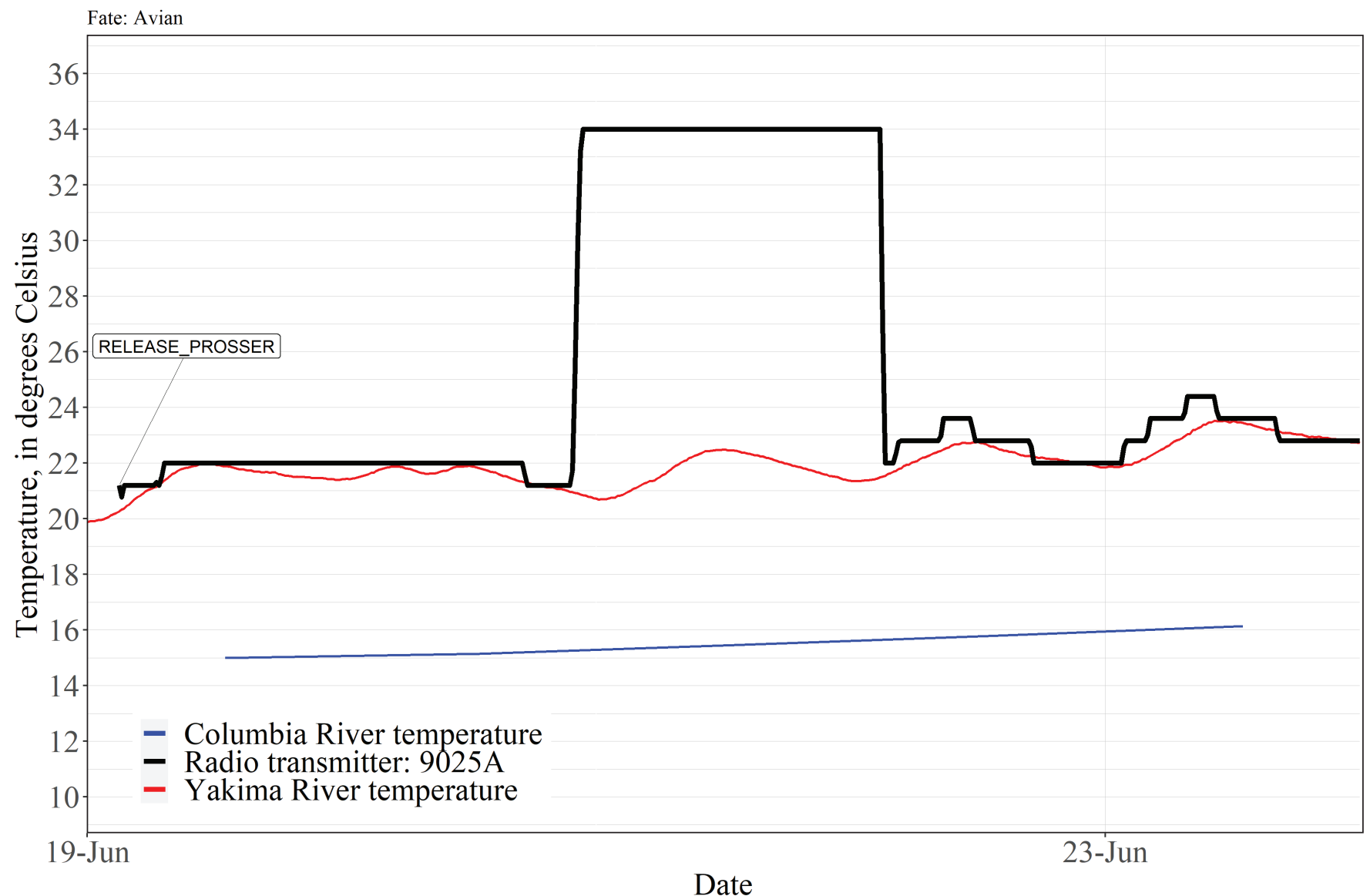

Figure 1.2. Water temperature use data (thick black line) collected by a radio transmitter inside an adult sockeye salmon (fork length 49 centimeters) tagged and released at Prosser Dam on June 19, 2020. Transmitter was recovered near the Chandler Fish Handling Facility on July 8, 2020. Temperature peak during June 21-22, 2020 likely was owing to the tag being inside a piscivorous bird. Water temperature data from the Columbia River (blue line; streamgage PAOW, Pasco, Washington) and Yakima River (red line; streamgage CFSW; Chandler Fish Screens) are included for reference. 


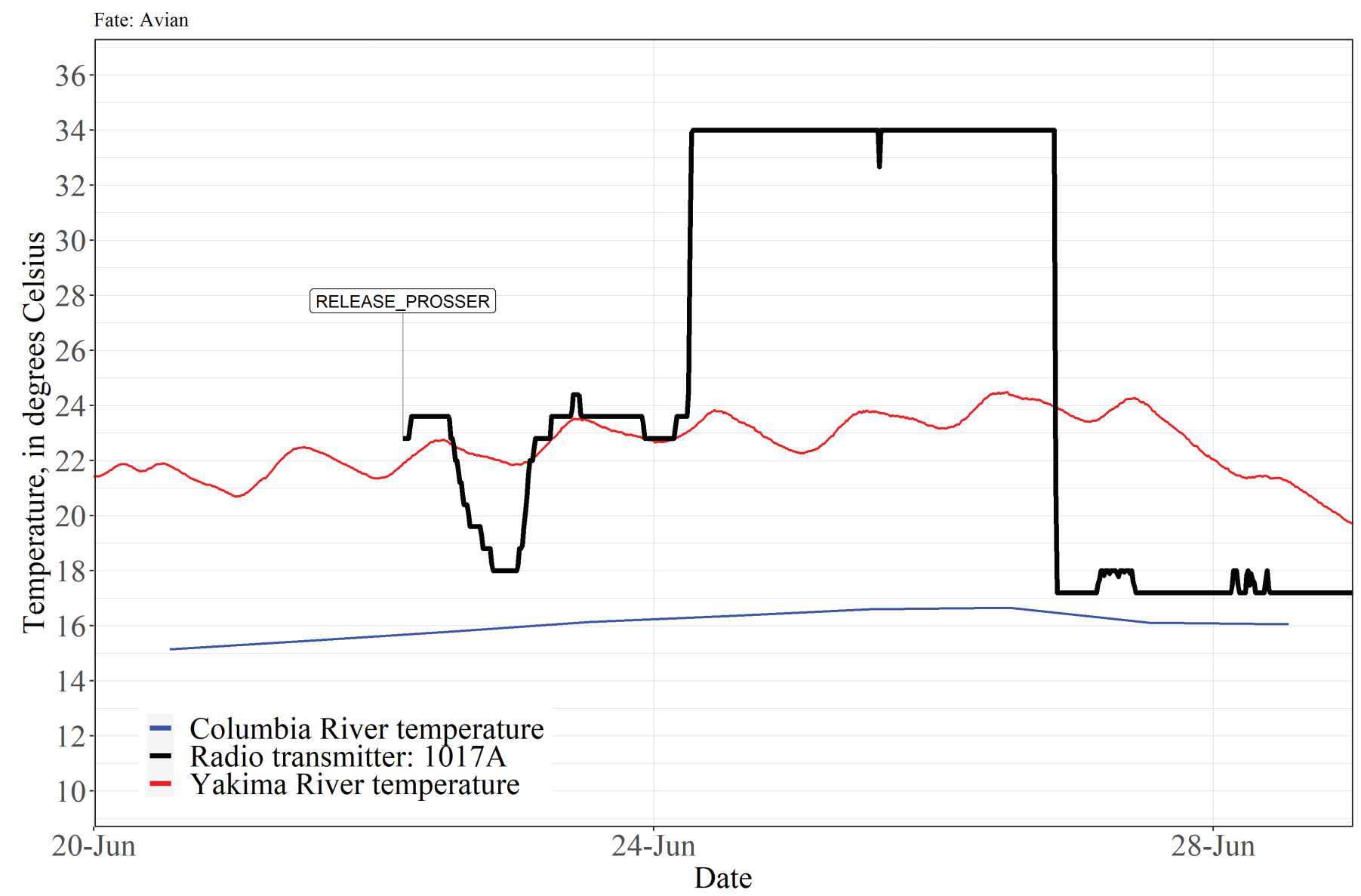

Figure 1.3. Water temperature use data (thick black line) collected by a radio transmitter inside an adult sockeye salmon (fork length 48 centimeters) tagged and released at Prosser Dam on June 22, 2020. Transmitter was recovered in the tailrace of John Day Dam on October 27, 2020. Temperature peak during June 24-26, 2020 likely was owing to the tag being inside a piscivorous bird. Water temperature data from the Columbia River (blue line; streamgage PAOW, Pasco, Washington) and Yakima River (red line; streamgage CFSW; Chandler Fish Screens) are included for reference. 


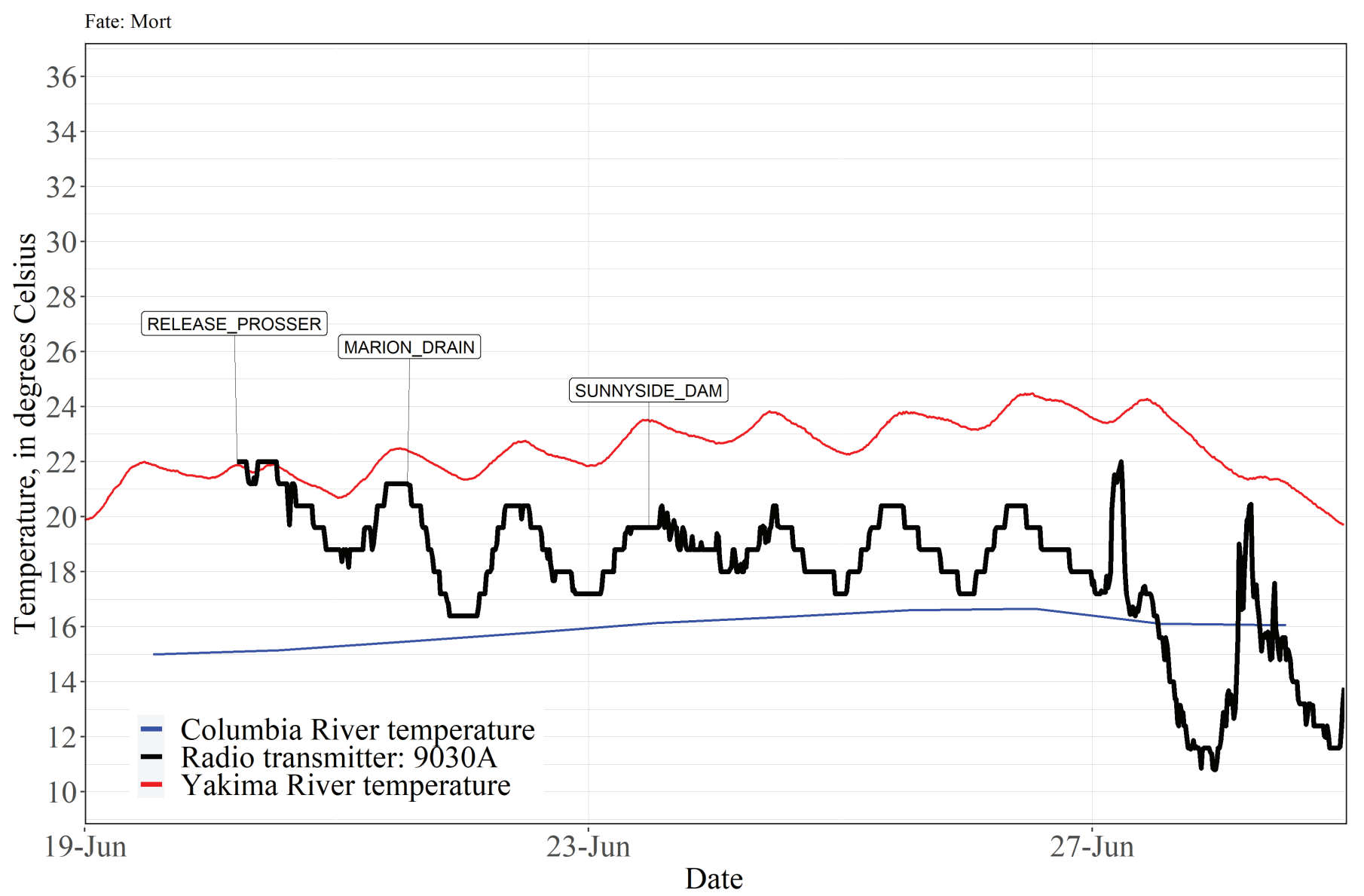

Figure 1.4. Water temperature use data (thick black line) collected by a radio transmitter inside an adult sockeye salmon (fork length 48 centimeters) tagged and released at Prosser Dam on June 20, 2020. Transmitter was recovered 6 river kilometers downstream from Sunnyside Dam on July 22, 2020. Water temperature data from the Columbia River (blue line; streamgage PAOW, Pasco, Washington) and Yakima River (red line; streamgage CFSW; Chandler Fish Screens) are included for reference. 
Fate: Mort

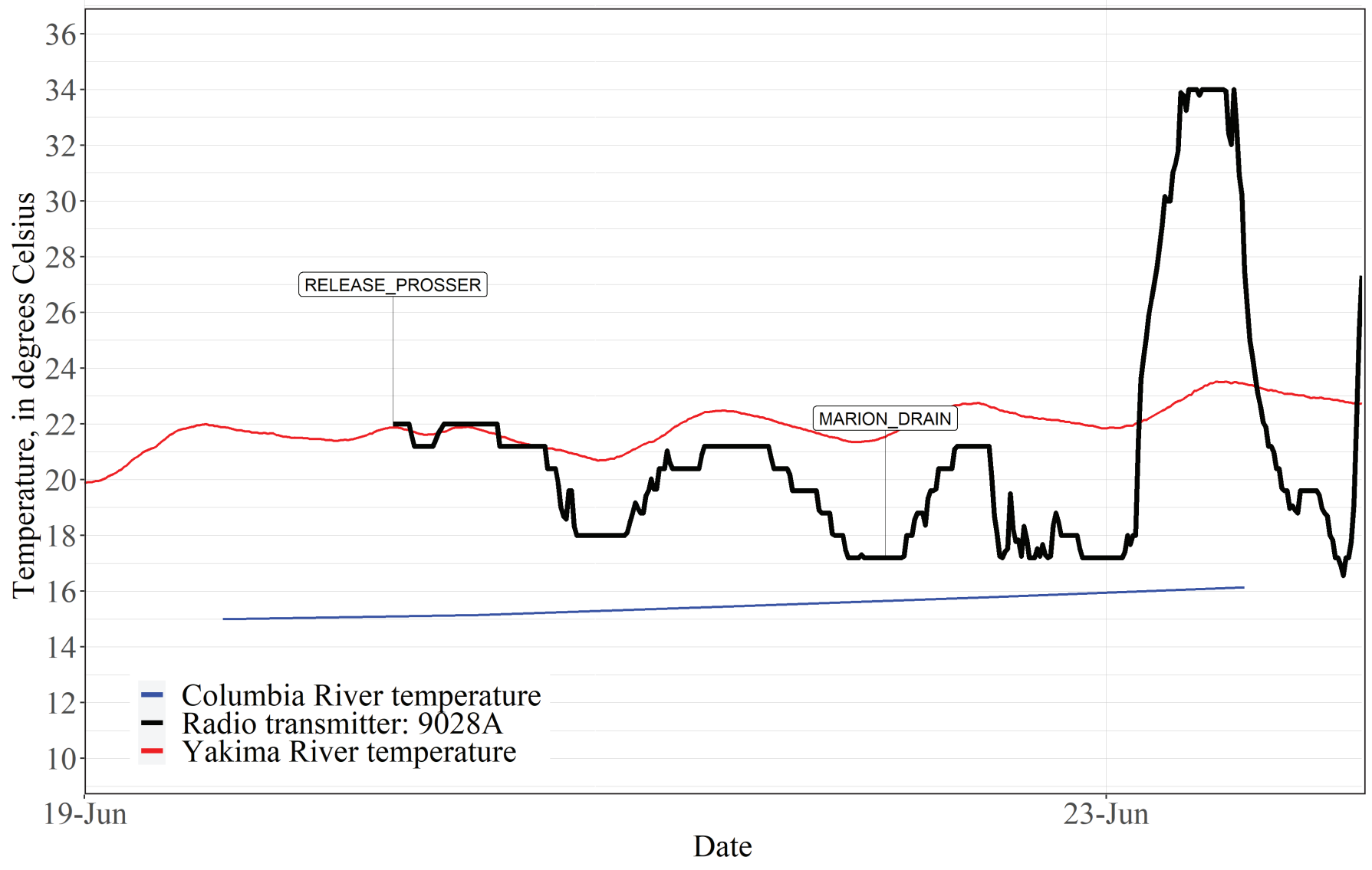

Figure 1.5. Water temperature use data (thick black line) collected by a radio transmitter inside an adult sockeye salmon (fork length 47 centimeters) tagged and released at Prosser Dam on June 20, 2020. Transmitter was recovered 16 river kilometers downstream from Sunnyside Dam near Buena, Washington, on July 22, 2020. Temperature peak during June 24-25, 2020 likely was owing to the tag being inside a piscivorous bird. Water temperature data from the Columbia River (blue line; streamgage PAOW, Pasco, Washington) and Yakima River (red line; streamgage CFSW; Chandler Fish Screens) are included for reference. 


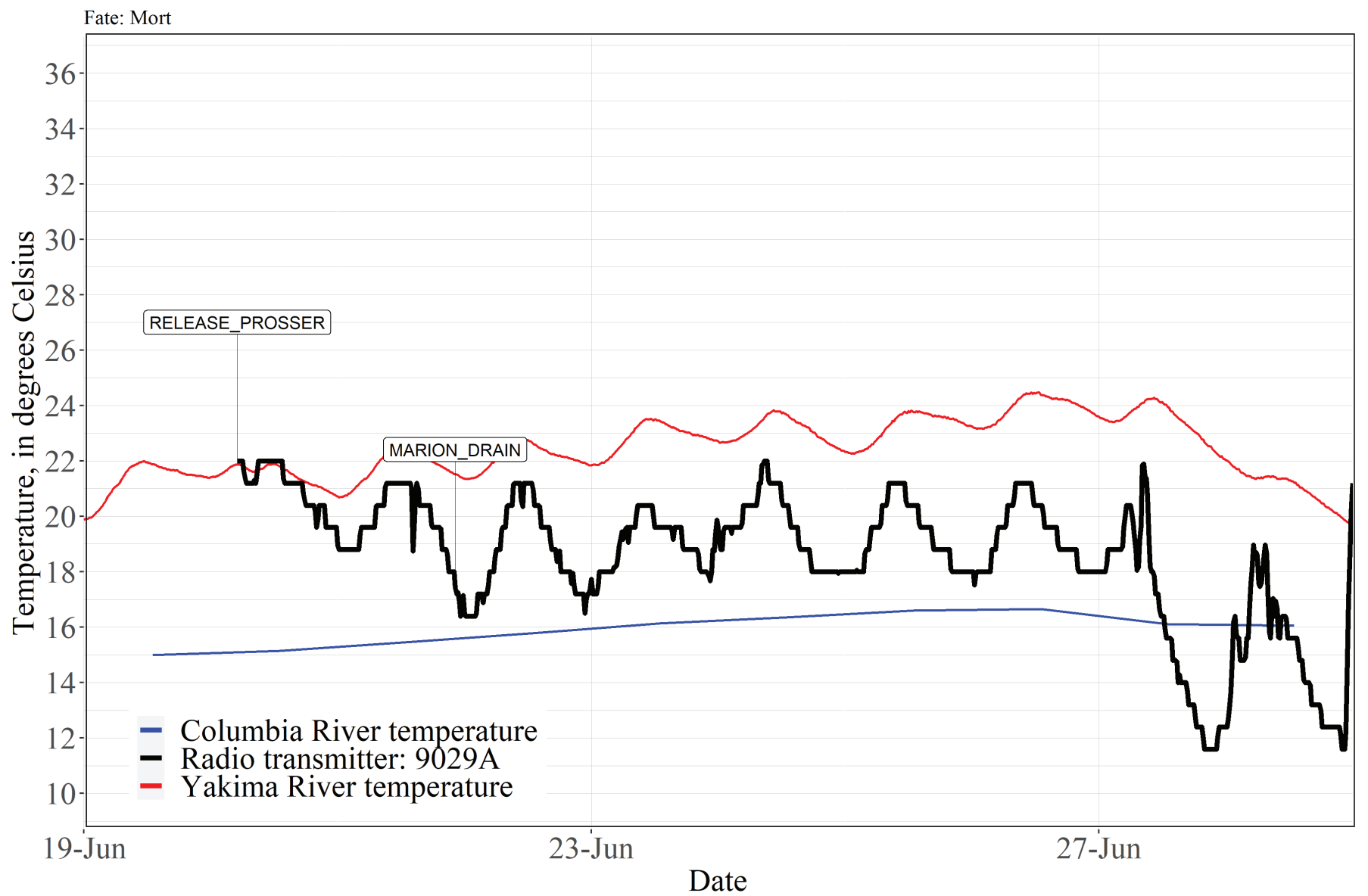

Figure 1.6. Water temperature use data (thick black line) collected by a radio transmitter inside an adult sockeye salmon (fork length 48 centimeters) tagged and released at Prosser Dam on June 20, 2020. Transmitter was recovered 16 river kilometers downstream from Sunnyside Dam near Buena, Washington, on July 22, 2020. Highly variable temperatures after June 26 likely occurred because the transmitter was not present in a live fish during this period. Water temperature data from the Columbia River (blue line; streamgage PAOW, Pasco, Washington) and Yakima River (red line; streamgage CFSW; Chandler Fish Screens) are included for reference. 
Publishing support provided by the U.S. Geological Survey Science Publishing Network, Tacoma Publishing Service Center

For more information concerning the research in this report, contact the Director, Western Fisheries Research Center

U.S. Geological Survey

6505 NE 65th Street

Seattle, Washington 98115-5016

https://www.usgs.gov/centers/wfrc 
6

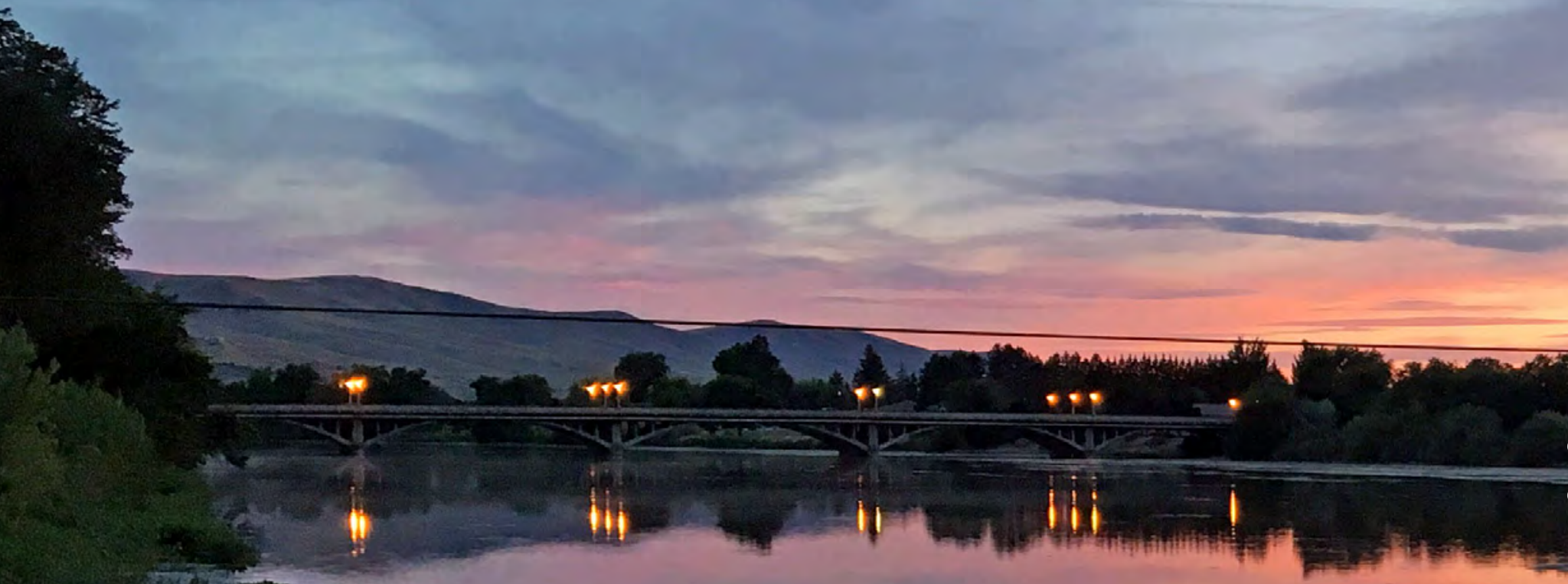

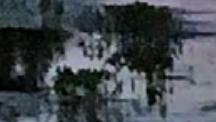

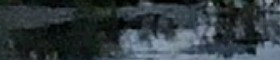

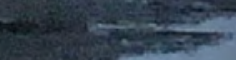

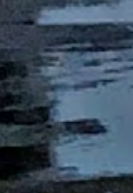

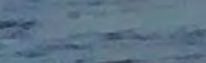

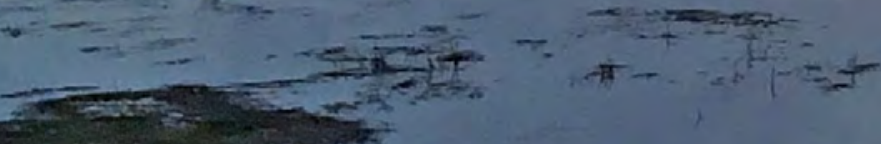

